\title{
BORDERS AND BEYOND: CONTESTED POWER AND DISCOURSE AROUND SOUTHEAST COASTAL CHINA IN THE SIXTEENTH AND SEVENTEENTH CENTURIES
}

\section{Boyi Chen}

\author{
Washington University in St. Louis \\ E-mail boyichen@wustl.edu
}

\begin{abstract}
This article focuses on the mobile peoples who engaged in piracy on the borders beyond the territories negotiated by the imperial Chinese and colonial Spanish and Dutch powers, and by doing so, reframe our perception of early modern imperial and maritime history. In premodern times, the control of territory within the administrative borders was incomplete, and small pockets of territories with porous borders were beyond governmental rule. The people and the groups that lived along the coast of the northeastern South China Sea were, at different times, recognized differently and many of their activities were at times sanctioned and at other times outlawed. This article reveals a facet of how the non-stateless peoples lived on the borders beyond, claimed their own order in their own way, and worked and became naturalized or classified inside the strengthening borders in pre-modern societies according to the agenda and discourses of the dominant powers. I argue that the coastal societies had their own "order" that created groups "beyond control" or "being registered gradually."
\end{abstract}

Keywords: border; beyond; pirate; register; order

Two significant pirate leaders, Lin Feng 林鳳 (Limahong, ?-I575?) ${ }^{\mathrm{I}}$ and Zheng Chenggong 鄭成功 (Koxinga, I624-I662) ${ }^{2}$, influenced the early modern borders around coastal

* This research was conducted with support from the project "Studies of Southeastern Coastal China and Social Economy from the Sixteenth to the Nineteenth Century" at the East China Sea Rim Research Institute (ECSR) of Zhejiang Normal University, where I serve as Adjunct Research Fellow. First and foremost, I offer my sincerest gratitude to my friends Dr. Chris White, Dr. Seiji Seiji Shirane, and Jonathan A. Chu, who have offered me much great advice and helped me revise my article. I need also to show my gratitude to Prof. Michael Szonyi, who gave me a lot of feedback and encouragement at the I6th Annual Harvard East Asia Society Conference. I am also indebted to my advisors, Prof. Steven Miles and Prof. Lori Watt, who have supported me throughout my article with their patience and knowledge whilst allowing me the room to work in my own way.

I Compared to Zheng Chenggong, Lin Feng is less known by people and only a few scholars have written about his stories. See Zhang I930, pp. I473-83; Li C. I93I, pp. I869-I87 I; Li G. I93I, pp. 206I-208I; Chen I934. For a general description of Lin's uprising and its legacy, see See 2013, pp. 290-302. The Spanish archives describe the process of Lin's attack, see Agustín, pp. 40I-5, 435, in Lee 2008, pp. I45-49.

2 Zheng is very prominent in Chinese scholarship but only recently has an English monograph fully discussed his activities and influence; see Hang 2016. 
southeast China in the sixteenth and seventeenth centuries in different ways, revealing a borderless reality beyond the ideal Chinese imperial and European colonial claims, urging us to reflect on the original social "order" in a different way. This reality further relates to piracy, strengthening administrative borders, European colonial settlements with their new borders, along with regional barriers and the spaces occupied by borderless people. Born in Chaozhou (Teochew), Lin attacked the Spanish-controlled city of Manila, and then fled to the Pangasian region in 1574 before disappearing from the Philippines and becoming a legend in Cambodia and the Malay Peninsula. Zheng, having lost a chance to save his Japanese mother, Tagawa Matsu, from the Manchu army (I646), fought a life-and-death struggle with the Qing (I644-I9I2) court and seized Taiwan as a base from the Dutch in r662. At one time he controlled both commercial and pirate ships from Nagasaki to Melaka. The two pirates Lin and Zheng established maritime dominance during their time, reshaping the order and borders of the sea basin and the region together with their enemies, as well as bringing with it by-products of discourses up to the modern era. This article, due to limitations of space, will focus on those mobile people who shaped piracy and the borders beyond those negotiated by the different powers, and further reframed our perception of early modern imperial and maritime history. I argue that the coastal societies had their own "order" that created the groups "beyond control" or "being registered gradually."

Previous studies have proved that the pirates and the merchants on the early modern Chinese southern coast were generally the same people-coastal natives. ${ }^{3}$ These people, either "outlawed" or "law-abiding," as well as most of the commoners, took on the identity of pirates or merchants in order to reap different benefits, moving back and forth between these two categories or identities. Similarly, Western Europeans and Chinese officials alternated between labeling these people "pirates" as well as "merchants," depending on whether they wished to oppose or cooperate with them. However, after understanding this situation, we may push the conclusion further to see if this "pirates as well as merchants" model shadowed some facets of the coastal societies in terms of "order" and the groups beyond social control. The reason different subjects needed to label others was that they collided with each other right there at that time; in other words, the empire tried to strengthen its administrative border in the context of the borders beyond. Along with this new consolidated border was the creation of new identities. This article focuses on administrative efforts in southern Fujian and colonial Manila and Dayuan (Tayouan), people outside the Chinese empire's control ("outlaws"), and the negotiation between people and power. It first reviews the scholarship on border issues, then on the nature of the pirates, then examines the colonial process of the Spaniards and Dutch, and finally moves to describe how the historical processes above shape our understandings of the past. The borders beyond were clarified day by day under several strong powers, and historical discourses and consciousness were shaped under the newly strengthened administrative borders.

To define the "borders beyond" or the "borderless," we will clarify how borders were, in fact, drawn around southeast coastal China in the sixteenth and seventeenth centuries. From an external perspective, Chinese imperial authority generally considered the 
coastline, including the coastal islands, as its southeast border. After Taiwan was incorporated into the imperial administrative settlement, it also became the southeast "hedgerow" of the empire. ${ }^{4}$ The Spanish colonialists considered northern Taiwan as their border until their forts were taken over by the Dutch, while the Dutch considered the coastline, which covered the ports of Zhangzhou and Quanzhou, their front line as well as their maritime border. 5 Outside these regions, Chinese, Spanish, and Dutch administrators, in their view, perceived these as the borders beyond, whether of land or sea. However, from an internal perspective, these three powers all faced inner barriers which created the de facto borders beyond. These borders beyond included communities no smaller than the area inside the "border" controlled by the administrators, including many villages and towns (although not all). The administrators understood what separated their own territory from mobile people, but they had less control over what went on inside their borders. In other words, control of territory within the administrative borders was not complete, and small pockets of territories with porous borders were beyond their control. For instance, the Dutch only controlled the small areas around Zeelandia, their fort in south Taiwan, and the Spaniards even in the I630s were able to hide inside their fortress in Danshui (Fort San Salvador). ${ }^{6}$ The Ming government effectively controlled the prefectural seats; however, within its territory were several restless areas, with several groups of equally restless people, who also moved beyond their borders. Most of those, the Chinese imperial and European colonial authorities labeled as the pirates and merchants described in this article, people who lived in these borders beyond, and moved back and forth inside and outside them.

\section{LITERATURE REVIEW}

Few English-language works have tried to connect the border issues of this region in the pre-modern world to the activities of these mobile people, who were part pirate and part merchant. Ng Chin-Keong's recent book, by compiling most of his previous articles over the past two decades, uses the concept of boundaries "to explain the development of China's maritime southeast and its interactions across maritime East Asia and the broader Asian Seas." 7 Harriet Zurndorfer summarizes recent western scholarship on this topic to look at how the "maritime" turn changed our sense of continental history. ${ }^{8}$ Tonio Andrade demonstrates that the Japanese, Dutch, and Spaniards had different understandings of the territoriality and taxation rights in the case of Taiwan (especially its eastern part) in the first half of the sixteenth century. ${ }^{9}$ Although this problem had disappeared after the expulsion of the Dutch by Koxinga and by the later Chinese administration of Taiwan, ${ }^{\text {Io }}$ the same issues would be revived again in the nineteenth century, when

4 Teng 2004, p. 44.

5 Borao 200I-2002.

6 Andrade 2008, pp. 80-99.

$7 \quad \mathrm{Ng} 2017$.

8 Zurndorfer 20I6, pp. 6I-94.

9 Andrade 2008, pp. I-99.

Io Emma Teng's work helps to explain "how an island that was terra incognita for the better part of Chinese history came to be regarded as an integral part of China's 'sovereign' territory." See Teng 2004, p. 7. 
Japan adopted and mimicked the attitudes of Western imperialists in the 1874 Taiwan

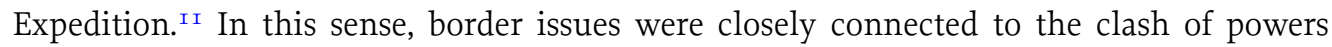
and the shaping of historical discourses in connection with these mobile people in modern times.

How the regional powers went about controlling these mobile people has also been an

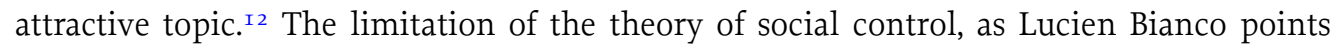
out, is that while it defines control as the prevention and repression of incidental disorders, it can no longer use the definition itself to analyze the lack of unrest. ${ }^{\text {I3 }}$ Plus, the theory of social control completely fails to explain the mechanisms of disorder. The bankruptcy of the social control theory in social history after the I96os makes it vital to rethink the basic order of society (how local organization was manipulated) in late imperial China. ${ }^{14}$ From the I990s until now, the mainstream local control discourse was set under ritual practice and the lijia 里甲 system. ${ }^{15}$ This dominant discourse has, so far, repeatedly pushed scholars to discuss the mechanism of social control. This article inherits the legacies of these social history studies by focusing on people beyond "control" and hopes that by revealing this reality we can understand the keys to social disorder and admit that society had, in fact, its own order.

Southeast coastal China in the sixteenth and seventeenth centuries can be described as a world of "pirates" and "merchants." Previous scholars have for a long time taken note of the topic of pirates. Charles Hucker presents a case of how civil officials campaigned against invading groups in the context of traditional Chinese patterns of response to military threats. ${ }^{16}$ Kwan-wai So addressed the same problem in the I970s, but he only focused on "Japanese pirates" while neglecting the fact that their equivalents were being nourished by unstable local society, or the places that we here describe as the borderless regions outside the control of the administrative government. ${ }^{17}$ Dian Murray studies the pirates of the late eighteenth- and early nineteenth-century South China coast and points out that the Vietnamese regime in the south supplied them with a fertile breeding ground, and Robert Antony brings another work of Qing piracy and "history from the bottom up" by revealing in micro-perspective the life of pirates, rampant disease, homosexuality, and violence. ${ }^{18}$ Recently, Dahpon Ho published his study on earlier piracy and Qing motivations for controlling the coastal people. According to Ho, his research portrays "the depopulation as not just a military act to combat pirates or the powerful sealord Koxinga (Zheng Chenggong), but also an act of social engineering to subjugate the coastal population by

I I Eskildsen 2003; Eskildsen 2005, pp. 388-4I8.

I 2 Kung-chuan Hsiao raised his famous theory of "social control" in the I950s, attributing all banditry and crimes to the loss of imperial control. See Hsiao i960.

I3 Bianco I962, pp. II75-82.

I4 Wakeman I966; Kuhn I970.

I5 Faure 2007, p. 368.

I6 Hucker I97I, pp. I-40.

I7 So I975.

I8 Murray I987; Antony 2003. 
removing it behind an artificial land boundary." 99 The current article, then, traces the earlier piracy and further reveals the key reasons behind the persistence of this piracy.

\section{PIRACY AND THE INTENSIFYING ADMINISTRATIVE BORDER}

The strengthening administrative powers reshaped borders and the borders beyond. Piracy represented a status closer to the original ecology of the borders beyond, and was a representation of the conflicts accompanying the process of the expansion of the Chinese imperial and European colonial powers. Ming dynasty (I368-I644) Chinese commentators referred to coastal pirates and some bandits as wokou 倭寇. This term literally means "[dwarf] Japanese bandits/pirates," though many of the pirates were Chinese from the southeast coast. To strengthen the feeling of the borders beyond and the background of piracy, we need to review the study of kou (all kinds of robbers such as bandits and pirates), including wokou (literally meaning Japanese bandits and pirates) and haikou 海寇 (generally meaning pirates).

\section{Studies of Piracy}

Beginning in the I89os and continuing into the twentieth century, Chinese historians paid a great deal of attention to the phenomenon of piracy. At that time, especially during the I930s to 40s, China was threatened by Japan, and this had much to do with why scholars were provoked to recall the history of wokou incursion. These early studies made a contribution in identifying primary historical sources and in providing fertile ground for introspection today. ${ }^{20}$ However, these works tend to have at least one of three characteristics that have placed limits on the development of the field: one a purely chronological narrative with little historical interpretation, another a rigid class analysis, and finally a simplistic view of Sino-Japanese relations. Prior to the I990s, such characteristics dominated research on the kou. $^{2 \mathrm{I}}$

Despite their contributions in identifying relevant primary sources, these Republican-era works share some flaws. First, they view wokou in the beginning of the Ming dynasty as being the same as wokou in the Jiajing reign (I522-I566). Such a perspective ignores the fact that these wokou groups were composed of different people and involved in quite different activities. More important is that almost all Chinese historians who wrote about the wokou before the I99os explained the sudden severe conflicts in the Jiajing period as resulting from the contradictions between the policy of the sea prohibition and private trade. Turning to studies from the I980s, even though they made great improvements, the characteristic of rigid class analysis persisted, or we can say that they shared paradigms with the works of the I930s. Furthermore, in much prior Chinese scholarship, such portrayals quickly led to discussions of "the sprouts of capitalism," "the movements of anti-feudalism," or the "revolution of the people." Such knee-jerk associations are the second characteristic found in much of the

I9 Ho 20I3, pp. 53-74

20 Wu I934, p. 29, 27; Wu I929; Chen 1939; Li I933; Wang I940.

$2 \mathrm{I}$

Shen 2005. In addition, some relevant works published before the I99os still deserve attention. See Li I956; Zheng I987, I988, pp. 75-86, I985; Wu I999, pp. 9I-106. 
previous research on wokou. Generally speaking, works from the Republican era (I9I 2-I949) tended to have the first and the third limitations, while works from I949 to the I 980 os tended to have the second and the third limitations.

These associations could be found even in otherwise outstanding works. However, Dai Yixuan in I982 successfully changes the "traditional view" by moving away from viewing wokou as Japanese bandits to seeing them as Chinese, either bandits or commoners, and Lin Renchuan in 1987 finds that even from another standpoint we can recognize this fact: of the fifty-three identifiable wokou leaders, at least forty-four can be confirmed as Chinese (83 percent). Hence, Lin makes the clear judgment that, in the Jiajing reign, it was really not the Japanese bandits but the anti-prohibition struggle of the maritime commercial cliques and the anti-repression struggle of the coastal peasants that caused the unrest.

Although Lin shows some cases in which the wokou were at the same time merchants, we cannot simply attribute wokou incursion to a so-called maritime commercial clique, nor can we simply characterize them as fugitives, for such categories would necessarily obscure the complexity of the living habits and activities of coastal populations. If wokou incursions were really rebellions by maritime merchants, why do we, in the primary sources, see such passages as "the merchants are so frightened when they hear rumors of wokou," but find no evidence of merchant-wokou collusion? Some of the primary sources prove the limitations of these explanations by scholars prior to the ${\text { I } 990 .^{22}}^{22}$

In the primary sources of the Ming dynasty, it seems that the bandits in South China had many qualities in common and often blended into the general population. In the Jiajing reign, the scholar-official Gao Gong 高拱 wrote that "it is not the people who become bandits, but the whole of Guangdong is full of bandits. It is all because of this situation [that local officials and generals collude with the bandits]." 23 The existence of such bandits was typical for most areas of southeast China. Such groups were a mainstream part of the social milieu of the area, and people who were willing to rebel on a small and local scale were very much a part of the local society along the coast, the original borderless place. ${ }^{24}$ An assistant of the Zhejiang and Fujian Grand Coordinator wrote in the sixteenth century that "the people who had capital would collude with the wokou to trade; those who had little capital would collude with the wokou to rob; the really powerful and rich families would cover such activities, and the officials can only negotiate with [the wokou]." 25 In fact, people in the mid-Ming found that the phenomenon of the wokou started when the rich, powerful families found ways not to pay for their goods, while at the same time, "The ordinary people were also oppressed by corrupt and fierce officials and distressed by hunger and cold. They then followed one another into the sea." ${ }^{26}$ Besides this local power, another problem was that the kou were mobile. Though they could be suppressed in one area, it was fairly easy for them to move to a new area that was more lax in state control. Likewise, the kou strengthened both this mobility and social networks through marriage ties.

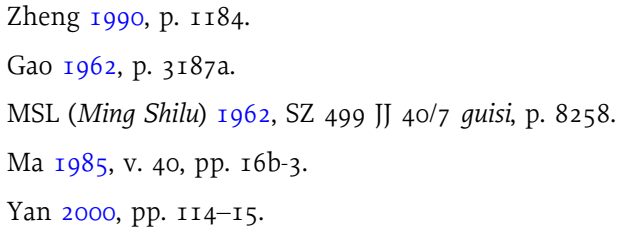


Aside from the mainland Chinese scholarship discussed so far, scholars in Taiwan and Japan also discuss piracy from a social historical perspective. In addition to emphasizing the waxing and waning of prohibitions on maritime activity, Zheng Liangsheng and $\mathrm{Wu}$ Daxin have also tried to place wokou in the broader framework of South Chinese social history. Zheng's book is a very solid study with rich commentaries and research, which benefits later scholars in providing the chronology. Japanese scholars have also made a substantial contribution. ${ }^{27}$ Katayama Seijirō and Sakuma Shigeo's works and ideas were introduced to China very early on. ${ }^{28}$ Katayama Seijirō has noted the rebellions. He is influenced by earlier ideas about community and gentry, hence is most interested in the inner motive power. In formulating his ideas, he focuses on the independent movement of people in Haicheng. This, then, led his discussion back to the maritime prohibition policies. ${ }^{29}$ In Japanese scholarship, the focus on Sino-Japanese relations pushed scholars to appreciate the maritime perspective very early on, though its by-product is the concentration by and large on trade, tribute missions, and the "pirate as well as merchant/envoy" model. ${ }^{30}$ This framework is constructed by Ng Chin-Keong and Jennifer Cushman, who challenged the tribute system as a referential framework of Chinese trade overseas. ${ }^{3 \mathrm{I}}$ Murai Shosuke, an authority on this topic, also takes the view that wokou who attacked Ming from the fourteenth to the sixteenth centuries comprised multi-ethnic groups who played a significant role in Sino-Japanese maritime trade, including the official business among governments. ${ }^{32}$ Later, Nakajima Gakusho reveals that the international trade order of East Asia was reorganized into the so-called "I570 system" in which various trade routes coexisted and interacted. 33

The study of kou provides some insights into the significance of state formation in the twenty-first century. Chen Chunsheng adds haikou into the discussion and views this group as a continuation of wokou. Chen's research, based on his investigation of local society, shows how the southeast coastal people and society were integrated into the empire in the Ming-Qing era. ${ }^{34}$ From Chen's perspective we can easily find that wokou groups in the early Ming dynasty are quite different from those in the mid- and the late-Ming periods. ${ }^{35}$ It is clear that they were "created" by two different societies. Chen also indicates another way to approach the phenomenon of wokou, by studying the process of their disappearance. The earliest chronological narratives or historians who upheld previous conventional views on Sino-Japanese relations tended to regard General Qi Jiguang's 戚繼光 (I528-I588) final military victory over the wokou as signaling the disappearance of this

27 For instance, earlier researchers such as Fujiie Reinosuke and Tanaka Takeo, see Tanaka I96I.

28 Zheng I985; Wu 1999.

29 Katayama I962, pp. 389-420.

For example, the most representative scholar in early modern Japanese history considers the smuggling trade and the trading system of Nagasaki as a "Japanese adaptation of a Sinocentric rhetoric governing foreign relations with tributary states". See Arano 2005, pp.I85-26r.

Ng I983; Cushman I993.

32 Murai 2005. 
group. This military general was famous for eliminating the wokou raiders. Hence, Chen points out that the explanations of both a military subjugation and a policy to open up previously prohibited trade are able to elucidate the wokou's disappearance in some ways, but such explanations cannot account for the continuation of the haikou. ${ }^{6}$ This article, based on Chen's search on how marginal people and society came into the national system, reveals how marginal people and the state powers shaped the local order on the borders and beyond.

To prove the validity of this "local order" interpretation, it is first necessary to refute the myth of the market, policy, and smuggling. Discussions about policies of sea trade and capitalism often quote the words of the scholar-official Tang Shu 唐樞 (I497-I574), who worked at the Ministry of Justice: "When the market was working well the bandits were all merchants, when the market was prohibited the merchants became bandits." 37 This remark is cited as solid evidence that the unrest caused by the wokou was a result of the technical prohibitions on private sea trade since the founding emperor of the Ming. These scholars argue that when the market periodically opened up, profits from smuggling declined substantially. More "normal" trading activities were then conducted, since there was no need for "illegal armed smuggling." However, a critical view of such an analysis shows that even after the market was opened up during the Longqing reign (I567I572), armed smuggling continued to exist and, in fact, was quite active all the way to the late Ming. After Lin Feng attacked Manila, Wang Wanggao 王望高 (Omocon), Fujian's Squad Leader, went to Manila in search of Lin. ${ }^{8}$ After the Spaniards repulsed Lin's attack, they sent a mission to the viceroy of Fujian, who welcomed them, sending them luxurious presents and asking them to eliminate the pirates. ${ }^{39}$ In fact, earlier, in letters from I574, Guido de Lavezaris (I499?-I58I?) had mentioned the numerous pirates that were harassing the trade along coastal China..$^{\circ}$ This happened after the Longqing period, a time which was thought to be the golden era of the "open" policy in Haicheng. ${ }^{4 \mathrm{I}}$ It seems obvious that neither the "prohibition" explanation nor the "merchant-bandit" explanation is sufficient. In fact, trade, smuggling, and even unrest are often different aspects of a single phenomenon: they are all different forms of group behavior that are often hard to distinguish from each other. In this borderless space and background of piracy, the escaped Lin Feng and the organized groups under the control of Zheng are meaningful.

\section{Enforcing the Administrative Border}

Imperial China expanded effectively, especially after the fifteenth century. Along its southeast maritime frontier, the empire enforced its control in every prefecture, from Ningbo, Taizhou, and Chuzhou in Zhejiang province, to Fuzhou, Quanzhou, and Zhangzhou in

36 For further discussion of this, see Chen 2009b.

$37 \mathrm{Xu}$ I962, p. 4334a. Katayama I953, pp. 23-32; Chen I965, pp. 375-48I; Huang I988.

38 “Omoncon”, see Mendoza I853; I998, p. I6r. TPI, Vol. VI. However, Vol. IV recorded this as "Omocon.” see TPI, V. IV, pp. 22-97. "Howoncon/Omoncon," see Boxer I953, p. I83, n. I.

Hudson I96I; 2004, p. 2II; Chen 2009, pp. 8I-IO8. 
Fujian province, to Chaozhou, Huizhou, and Guangzhou in Guangdong province. The seats of these prefectures were no longer isolated imperial bases as they had been in the Tang (6I 8-907) and Song (960-I 279) dynasties, although the extension of imperial political control was not smooth. One of the central issues the empire had to handle was local power. The issue around local power was not simply a central/local division, since some high officials in the court were the allies of, or even came from, these local powers.

Besides the issue of local power, one particular form of the local power in southeast coastal China was piracy, which caused much trouble for the empire. The history of the southeast coast of China between I500 and I700 is inseparable from the issue of piracy. Zhu Wan 朱紈 (I494-I550), the head of the Ming coastal defense for Fujian and Zhejiang, once tried to challenge powerful families. He raided many of the hiding places of the wokou and put more than ninety people to death. ${ }^{42}$ However, his action provoked those families to rebel and he was later impeached, leading to his suicide. Before taking his own life, Zhu was reported to have said, "It is still possible to get rid of foreign bandits and pirates, but especially difficult to get rid of Chinese bandits and pirates. It is possible to get rid of Chinese coastal bandits and pirates, but especially difficult to get rid of Chinese noble bandits and pirates." 43 The bandits and pirates also strengthened both mobility and their social networks through marriage ties, although it might begin with force, as Zhu Wan bitterly criticized: “Xu Fu 許福, a national civil service degree holder of Tong'an County, whose sister was robbed by pirates, joined with them after she married one of them. The result was that their family became rich." 44 Their borderless status was as a Ming literatus declares: "Unscrupulous merchants in Fujian and Guangdong became accustomed to having contact with the barbarians. They elected rich and powerful people as the head of each ship, with valuable commodities inside and other private goods to exchange. They got hundred-fold profits." 45 From the perspective of "unscrupulous merchants" and pirates, the complaints of the officials ("became accustomed to having contact with the barbarians") reveal that the empire was trying to interfere with the borders beyond. Conflicts became unavoidable.

In the context of this loose coastal border the empire was limited in establishing its administration, although its power was enforcing fixed borders. Scholars have discovered that the Maritime Trade Office (Shibosi 市舶司) was transferred from Quanzhou to Fuzhou around the Chenghua (I465-I487) to the Jiajing reign since there were too many "unscrupulous merchants" in Quanzhou..$^{46}$ Even as late as the mid-sixteenth century, when the Ming court chose a place to establish the Tariff Supervising Bureau (Duxiangguan 督館館), it had to change the original location from Meiling 梅嶺, where pirates were active, to another place close to the central Zhangzhou Prefecture seat. An early seventeenth-century book, Dong xi yang kao (Research on the Eastern and Western Oceans), written by a local Zhangzhou literatus Zhang Xie 張䁓 (I574-I640),

$\mathrm{Gu} 1977$, t. 3, p. 846 .

Zhang 1974, pp. 5404-5.

Zhu I962, p. 2158.

Zhou I935, No. 2954(2), p. 27. 
records an instance in which bandits disrupted the opening of a port (Meiling) market, and that finally the government had to open up another port (Haicheng). 47 It is no doubt that even this valuable port, Haicheng 海澄, took the empire a little time to confirm as the solid border. ${ }^{8}$ In the fortieth year of the Jiajing reign (I56I), wokou attacked Haicheng, but people in Haicheng took this chance to respond by "proclaiming "Twenty-four Leaders' and taking control of the sea for a long time," in the name of resisting wokou, but the government then quickly labeled them also as wokou. ${ }^{49}$ Influenced by previous Japanese scholars' ideas about community and gentry, Katayama Seijirō studies the inner motive power driving this rebellion. In formulating his ideas, he focuses on the independent movement of people in Haicheng. However, he leads the discussion back to the maritime prohibition policies..$^{\circ}$ In fact, this port did not emerge as an important market until well after the removal of the embargo in I567, taking some two decades to achieve real prosperity. ${ }^{5}$ Enforcing the administrative border took time, and during this time all sides used identity discourse to support their agency. We should focus on that local knowledge in terms of how these local people (pirates, local elites, merchants, and commoners) presented themselves, rather than the grand discourse left by the state.

We will now make a detailed inquiry as to why these people became wokou or why they were named wokou. Taxation and brokerage in the context of local administration played a central role in this process. It is easy to understand that despite the rebellions and attacks, one way the government enforced its authority was through taxation. However, this might have driven even more people to join the outlaws. The scholar-official Zheng Xiao 鄭曉 (I499-I566) gave a good explanation for the reason for this state of affairs:

The big civil and military officials cannot restrain their troops, and the local officials often abduct the rich using military law. They wildly extort and impose tariffs ... from the initial wokou entrance into Huangyan 黃岩 County until now, ten years have passed and most people in Fujian, Zhejiang, Jiangnan, Jiangbei, and Guangdong have followed the wokou.... People who were evil and fond of benefits liked the arrival of the bandits and they have used this occasion as an excuse to avoid taxes and corvée conscription..$^{2}$

The mid-Ming scholar-official Tu Zhonglü’s 屠仲律 memorial to the emperor tells us they were supposed to be registered people; however, they were not under direct official control in reality since they lived in the borders beyond. Regarding such wokou, Tu concluded:

Zhang I98I, pp. I3I-32.

In the ninth year of the Jiajing reign (I530), the Grand Coordinator and Censor-in-chief Hu Lian suggested moving the Coastal Patrol Circuit to Zhangzhou, but the "Office of Pacifying the Border" was only set in Haicang. In the forty-second year of the Jiajing reign (I563), the Grand Coordinator Tan Lun applied to set a Coastal Defense Sub-Prefect and changed the "Office of Pacifying the Sea" to the "Office of Coastal Defense," see Chen i968, p. I7.

Ibid., p. I 6 .

Katayama I962, pp. 389-420.

Chen 2009a.

Zheng 2000, pp. II6-I7. 
We should cut off the source of unrest. The unrest of the maritime bandits results from evil people who trade with the foreign areas. The foreigners are in a proportion of nearly ten percent, the landless people may be twenty percent, the natives from Ningbo and Shaoxing account for nearly half, and the people of Zhangzhou, Quanzhou and Fuzhou are up to a ninety percent (yiren shiyi, liuren shier, Ning Shao shiwu, Zhang Quan Fu ren shijiu) 夷人十 一, 流人十二, 寧、紹十五, 漳、泉、福人十九. Although they were all named wokou, they were "really" [our] registered people (Qishi duo bianhu zhi qimin ye 其實多編戶之齊民也). 53

It is clear from the sources that such groups of bandits were formed from the local populace. One source in I56I records that "over half of the bandits in Fujian were native people." 54 Another author explains in I562 that “the bandits Lü Shangsi 呂尚肆 and Li Zhanchun 李占春 colluded with the surviving wokou of Fuzhou, Xinghua, Zhangzhou and Quanzhou and plundered everywhere." 55 It is apparent from such sources that the existence of such bandits was quite normal in the coastal regions. According to many Ming officials, it was the common view that wokou were such kinds of people during the Jiajing reign. ${ }^{6}$

\section{THE COLONIAL SETTLEMENTS AND THE NEW BORDERS}

There is another abundant body of scholarship in the context of Sino-Western interactions that works well in this field. Aside from the great achievements of earlier Portuguese eastward expansion and its impact in this region, which are fully developed by Charles R. Boxer, Roderich Ptak, and George Bryan de Souza, the interlaced Spanish and Dutch colonial scenes are also prominent.57 The Survival of Empire is definitely an outstanding monograph on the early Portuguese exploration and colonization in Asia, with solid statistics revealing the imperial business and those merchants and pirates who engaged in it. The parallels in the relationships among imperial administrators, merchants, and pirates, and between Portuguese and Chinese communal groups, makes clear that the Chinese initially considered all the Portuguese as pirates. This is also one noteworthy conception that defined the border and its distinction for the "uncontrolled" people. Compared to the Portuguese presence, the Spanish and Dutch were more active in the northeastern South China Sea, especially after the seventeenth century, hence, they played major roles in terms of the collision of borders and the dominance over cross-border people.

Manel Ollé eloquently points out that the Spanish changed their colonial "model" dramatically and strategically to accommodate the Chinese "factor" in the Asian ecology..$^{8}$

Tu I962, p. 2979b; MSL, SZ 422 JJ 34/5 renyin 壬寅, p. 73 Io. Here Tu does not mean a real ratio, but refers to a rough constitution of wokou and pirates, comparing the different regional natives to the foreigners.

MSL, SZ 489 JJ 39/10 dingwei, pp. 8I42-43.

Ye Xianggao found that the number of actual Japanese bandits never exceeded one thousand. See Ye I962, p. 5052a; Jiang I962, p. 4I53a; Mao I962, p. 2700b; Zhao I962, p. 2672 a.

Boxer I953; Ptak 2003; Souza 2004.

58 Rodríguez 2004, pp. 23-34. 
Leonard Blussé addresses the diasporic Chinese interaction with the Europeans within a broad context of European expansion and Southeast Asian local development.59 Some recent works also reveal that the outsiders of the northeastern South China Sea crossed the border to engage in this region. ${ }^{60}$ These studies map a basic but vivid scene of the imperial "encounter" and of the trans-regional people beyond the borders. At the same time that the Chinese empire was enforcing its borders, the Western European colonial powers also began to create some new borders (northern Taiwan and the Philippines) beyond southeast coastal China, and people who lived in the borders beyond had their own responses to this as well.

\section{Spaniards and Their "Western" Trading Networks}

The Spaniards, in search of spices, came to East Asia after the arrival of the Portuguese. Since they had first seized sites in America, once they successfully reached the South China Sea across the Pacific Ocean, they viewed the Philippine Islands as the Western Islands, which could be evident in their letters and reports. ${ }^{6 I}$ They tried to fight against the Portuguese in the Moluccas and were later defeated; hence the leader of the fleet had to surrender. ${ }^{62}$ A letter from Father Jerónimo de Santisteban to Antonio de Mendoza, the Governor of New Spain, proves that the disease and famine that the Spaniards suffered was profound. Hence, a truce was made between the Spaniards and the Portuguese, and part of the facilities on Ambon were abandoned. ${ }^{6}$ Still, the Spaniards needed a foothold: on September 24, I559, the King ordered Luís de Velasco, the Governor of New Spain, to seek to discover the islands opposite Molucca, despite a vexed domestic debate over the destination and routes for exploration. ${ }^{64}$ It was in ${ }^{5} 564$ that Philip II finally ordered Miguel López de Legazpi to lead a fleet to Luzon in order to avoid conflict with the Portuguese.

Then the trade between the Chinese and the Spaniards began, though it took several decades to thrive, during which the Spanish administration in Manila was trying to control the Chinese population. The Spaniards needed commodities made in China, while Chinese merchants were eager for silver, which the Spaniards extracted from the New World, especially in Potosi, South America. But the trading relationship was not built smoothly. ${ }^{65}$ The newly established trading relations brought both the Philippine authorities (a 6 percent

59 Blussé I977, pp. 290-309; I98I, pp. I59-78; I997.

60 Oka 20Io; Gil 20I I. James Chin also reveals that reliance on the sea for subsistence promoted the formation of an institutionalized Fujianese maritime trade network, see Chin 20I4, pp. 93-II2.

TPI, Vol. II, I52I-I569, "Preface," p. I2, pp. 23-43; Vol. III, I569-I576, p. I27; Schurz I959, p. 27.

62 TPI, Vol. II, “Preface,” p. I2; pp. 45-73.

63 Ibid., p. I3. In spite of this, Villalobos still discovered some southern islands and named them "Philippinas islands." See TPI, VIII, p. I27. According to José Rizal, only the southern islands were discovered, see Craig I927, p. 314. Abraham Ortelius's Indiae Orientalis, Insularumque Adiacentium Typus (I570) only mapped Mindono and Cebu, which also proves this fact, see Ts'ao I979, pp. 307-8.

64 It is the Treaty of Zaragoza (Tratado de Saragoça) made in I529 that restricted the Spanish expedition. Andrés de Urdaneta supported the action but thought it should be more cautious to avoid the region of Philippinas since it belonged more to Portugal. See TPI, Vol. II, "Preface," pp. I4-I5.

65 Chen 2009a. About the background and the statistics of the Philippine trade, see Schurz I959, Chaunu I960. 
import duty, generating over 30,000 pesos' income per year) and the Chinese merchants substantial benefits; the people living in Manila were also able to obtain numerous commodities. ${ }^{66}$ The rise of mutual exchange not only represents the manner in which the Chinese empire strengthened its administrative border or how the border gradually presented its potential power, but also reveals how borderless people were regulated under a "non-smuggling" rule while at the same time retaining their "outlaws" business in a creative way: the negotiation inherited the "smuggling" tradition of the local society since there were definitely more real trading ships than official ships (two on average per month).

The prosperity generated by increased commerce attracted a greater number of Chinese immigrants to settle in Manila, which became a problem for the Spaniards. In I547, the Chaozhou pirate Lin Feng heard that Manila was a new and relatively unprotected settlement. Seizing the opportunity to capture Manila, Lin Feng took nearly one hundred ships and several thousand men and women, along with seeds and cattle, to establish a new settlement in Manila. Upon arrival, Lin Feng and his troops found that Manila would not be an easy capture-the Spaniards resisted and conflict ensued. At first, Lin and his troops successfully attacked Manila and killed the Spanish commander Martín de Goiti (I534-I574), but they eventually grew weary from the unanticipated battle and thus fled to the Pangasian region to find a settlement. The Spaniards then pursued Lin to Pangasian and surrounded his settlement, leading to a four-month-long gridlock of skirmishes with Lin's troops. At last, Lin somehow escaped the Spanish blockade, fleeing the scene of battle.

After Lin's attempted conquest, and another case in which Pan Hewu killed the Spanish Governor-General in the I590s, the Spaniards grew paranoid about possible further Chinese settlements. Pan Hewu, one of the South Fujianese sojourners and the famous rebel leader in the sixteenth century, led laborers to kill Governor Dasmariñas and his soldiers-an astonishing incident at that time. ${ }^{67}$ In 1603 , the Spaniards suppressed the so-called "Sangley Rebellion," during which they killed many Chinese in Manila based on a suspicion from people such as Archbishop Benavides that the Chinese were trying to take over the Philippines. ${ }^{68}$ Interestingly enough, these Chinese merchants were neither associated with Lin Feng, nor were they engaging in piracy; the Spaniards, however, believed that they should not be underestimated as a potential threat. In the end, the failure of Lin Feng to settle in the Philippines, the mutual distrust created by a series of misfortunes, and the Spaniards' reaction in expelling the Chinese merchants changed the status quo in the trade between Fujian and the Philippines. This conflict was not the final one, as we can see what disaster Zheng Chenggong's victory in Taiwan brought to the Chinese settlers in Manila.

66 Qian I986, pp. 69-78.

67 For the Spanish records of this case, see TPI, Vol. XV, pp. 3I-287; Vol. XVI, pp. 27-209, 2I7-3I7. Pan's case is a common theme in the Chinese academic world, but it has been less stressed in English scholarship, although John E. Wills, Jr., and Edgar Wickberg et al. have mentioned it, see Wills I998, pp. 333-75. Only until recently has Zhang Xie's record of this case been translated and introduced, see Brook 2013, pp. I24-25. 
One of the following conflicts in 1662 proved this trouble, when governor-general Sabiniano Manrique de Lara was alarmed by Zheng's threat to invade the Philippines as well as forcing him to surrender. ${ }^{69}$ "The damned Dutch barbarians do not know the rule of nature and dared to mistreat our commoners,” Zheng said. “... Your small state is no different from the Dutch barbarians, who rode roughshod over our commercial ships.... I formerly intended to lead my troops personally to go on a punitive expedition."7o "Koxinga and his friends in Luzon conceived the idea of expelling the Spaniards. Their plot was discovered and the Spaniards murdered no less than 24,000 Chinese." ${ }^{71}$

Zheng's power, as mentioned before, grew very quickly after the I630s, especially in the I640s. By I655, even the Dutch were aware that he would not punish those who killed Dutch sailors if they gave up their stolen goods. ${ }^{72}$ In 1656 , he also threatened the Dutch and behaved very arrogantly. The Dutch had estimated that "time will tell us" what he would do. ${ }^{73}$ Indeed, with the development of his power and the shortage of the resources that he could get from the mainland, he gave the Dutch an answer by expelling them from Taiwan. ${ }^{74}$ Hence, Zheng's threat to the Spanish colonial authority was taken seriously. Zheng demanded that the governor-general surrender and pay tribute on April 4. The governor replied only after three months had passed, on July ro. He wrote for assistance from Spain and New Spain and sent ambassadors to negotiate, however, he also suspected that a group of Sangleys intended to rebel at the time once Zheng's troops had arrived. Hence, the Manila authorities pushed the Chinese into leaving the Philippines, as it would have been hard to get rid of all non-Christian Chinese "infidels" outside the captive region in Binondo and Parián.75 Many of the diaspora refused to follow the order to leave and relieve the uneasy authorities, and misfortune also occurred during the process of expulsion.

Despite a series of misfortunes, the Spaniards finally strengthened not only the border in the Philippines but also the maritime border north of the Philippines. At first the Spaniards tried to fight to push the Dutch away from the near coast of Manila. ${ }^{76}$ They also took over part of northern Taiwan in 1626, establishing Fort Keelung (San Salvador) there and developed the trade with Fujian more closely, as I have mentioned earlier.77 The Dutch continuously cut the trading route between Fuzhou and Keelung and Dansui. ${ }^{78}$ Plus, ships between Nagasaki, Manila, and Macau were also attacked.79 The

69 TPI, Vol. XXXVI, p. 219; McCarthy I970, pp. I87-96.

70 The original Chinese text was lost, while the Spanish version was kept, see Gonzalez I964, pp. 358-59. A Chinese re-translation, see Lai I954, pp. I9-20.

7I Alvarez I930, Vol. II, p. I32.

72 VOC I 202, fol. 57, see Cheng, pp. 424-25.

73 VOC I2 I2, fol. 2I, Cheng, p. 435.

74 For some recent studies, see Andrade 2013; Cheng 2013; Hang 2016.

75 TPI, Vol. XXXVI, p. $22 \mathrm{I}$.

76 VOC ro86, fol. 5, Cheng, p. 53.

77 VOC I09o, fol. I40, Cheng, pp. 65-66; VOC I096, fol. I2, Cheng, p. 90.

78 VOC rog6, fol. 4, Cheng, p. 92.

79 VOC I094, fol. 5, Cheng, p. 85. Zhilong's power also grew greatly (from Ioo junks to I,00o) after the rice prohibition and the ensuing hunger, see Lin 1965 , p. 9. 
Dutch gradually changed their tactics of intercepting and blocking after I636. One report shows that there were many ways to change the trading pattern, including developing their customs to trade in Dayuan 大員. ${ }^{80}$ Then there was no further need to intercept the junks to Manila: "The Chinese need our silver, just as we cannot live without their commodities." ${ }^{11}$ Two forts in northern Taiwan were lost to the Dutch in I642. ${ }^{82}$ The Dutch pressed further during $1645^{-1647}$ by attacking the Philippine islands fiercely, however, a treaty was made in 1648 to acknowledge the mutual benefits of trade. ${ }^{83}$ In short, by relying on the colonial settlement, the Spaniards clarified their northern maritime border in the first half of the seventeenth century, and gradually regulated people who crossed the border. Since the expulsion and killings of Chinese in I662, the authority emphasized the 6,000 restriction and maintained the non-Christian Chinese population sojourning in Manila at 5,000-6,000. ${ }^{84}$ The Spanish experience led to one dominant model of maritime order in Manila, while the Dutch's subsequent entry into this region led to another.

\section{The Coming of the Dutch and Their "East"}

When the Dutch first arrived on the Chinese coast, they were amazed that there were so many sampans or junks and that the population was so huge. ${ }^{85}$ Not surprisingly, they utilized the pre-existing trading networks when they came into this old world. ${ }^{86}$ They used the labels too, to divide the cooperative "merchants" from the uncooperative "pirates." They tried to take a port along the coast of China by force but failed; they tried to seize Macau from the Portuguese but were defeated. They attacked the "Haicheng-Manila" trading routes, and they launched wars against the Spaniards four times, and against the Ming government and the Zheng family several times. The Dutch had their agenda to deal with the complexity of their circumstances. In the northern part of Asia, they failed to get a foothold on the Chinese coast and had to move to Dayuan in southwest Taiwan. ${ }^{87}$ To the south, they needed to create another parallel fort to resist Bantam, which was at first controlled by the local chief, and finally they chose Jayakarta (Batavia). ${ }^{88}$ Hence, to realize their agenda in the north, finally a compromise was made and the trading routes became "Haicheng-Manila" and "Anhai (Zheng's base)-Dayuan." The key point we should not omit is that all these conflicts were a part of the bordering process against the background of piracy. In the Tianqi reign (I62I-I627), we again see the rise of pirates. Since the Ming

80 VOC III9, fol. I64, Cheng, p. I83; VOC II02, fol. Io, Cheng, p. II4.

8I VOC II32, fol. 569, Cheng, p. 22 I.

82 Francisco Navas and Pablo Pastells have compiled Spanish sources to show the Spanish failure during I64II642, see Borao I994, pp. 39-40.

83 Jin I990, pp. 223-25. During the same time, the junks controlled by Zheng grew considerably. Then, the major threat to the Spaniards shifted from the Dutch to Zheng.

84 TPI, Vol. XXXIX, p. I23.

85 VOC I077, fol. 3-40, pp. I8-19.

86 Prakash 1997; Blussé I997; Flynn 200I.

87 Andrade 2005, pp. 4I5-44. Even pirates were invited by the Dutch to live in these Chinese villages, see VOC I090: I96-206, fol. 202.

88 Blussé i98I, pp. I59-78; Wu I996, pp. 3i-34. 
court failed to extend administrative registration to all the borderless people, there were numerous people who were considered to be outside the government's control, while at the same time, soldiers and bandits easily exchanged their identities. The Dutch also originally used the term "pirate" to refer to these peoples, but later referred to them as merchants after the Dutch and Zheng Zhilong 鄭芝龍 (Nicolas Iquan Gaspard, I604-I66I) formed contracts, although the so-called pirates remained active until the end of the Ming dynasty. ${ }^{89}$

Between the forces of the Chinese empire and the colonial powers, small groups of pirates combined to form several concentrated groups in response. The Ming government and the Dutch tried to pacify the pirates and utilize them to eliminate other "uncontrolled" groups, which also accelerated the concentration of pirate groups. The process of concentration took several forms: conquest, military pacification, or fights between different factions. The empire also asked the Portuguese for help in eliminating the pirates. ${ }^{\circ}$ The final concentration of pirate power was when Zhilong, previously thought to have surrendered, was victorious in uniting or defeating all pirates. However, the situation was not completely stable, as Li Kuiqi 李鬼奇, Zhong Bin 鍾斌 and Liu Xiang 劉香 “rebelled” one after another, leading to the reappearance of pirates. In general, though, Zhilong and his son Koxinga were successful in controlling these groups.

Zhilong’s father, Zheng Shaozu 鄭紹祖 (or Zheng Shibiao 鄭士表), had been a minor official in Quanzhou prefecture. ${ }^{91}$ When famine swept through Fujian, many people came to seek shelter with Zheng's family, and Zhilong became powerful. Referring to Zhilong, one source records that: "He was familiar with the sea when he was a child, and he was surrounded by pirates. After Zhilong joined with the Ming government, no ships or junks could navigate without his flag." 92 Zhilong also built a base at Anping, where he kept his army. He created his own financial system and did not need to ask the government for support. He imposed taxes on commoners and asked the rich and powerful families to donate to his coffers. When the Dutch first came into the region they clearly recognized "the monopoly of the grand Chinese merchants." 93 They described Li Kuiqi and Zhong Bin's rebellion, after Zhilong had joined sides with the government.94 In fact, Li Kuiqi competed with Zhilong for the alliance of the Dutch. ${ }^{95}$ It is recorded that Li "defeated Iquan's army, seized the Chinchew (Zhangzhou) gulf and surrounded Amoy (Xiamen), causing the merchants to be unable to connect with each other at sea, so the trade vessels could not be seen in Tayouan (Dayuan)." 96

By I637, Zhilong had control over the sea area from Melaka to Nagasaki, from Southeast Asia to the Northeast Asian maritime basin. The Dutch had to surrender; hence, they chose

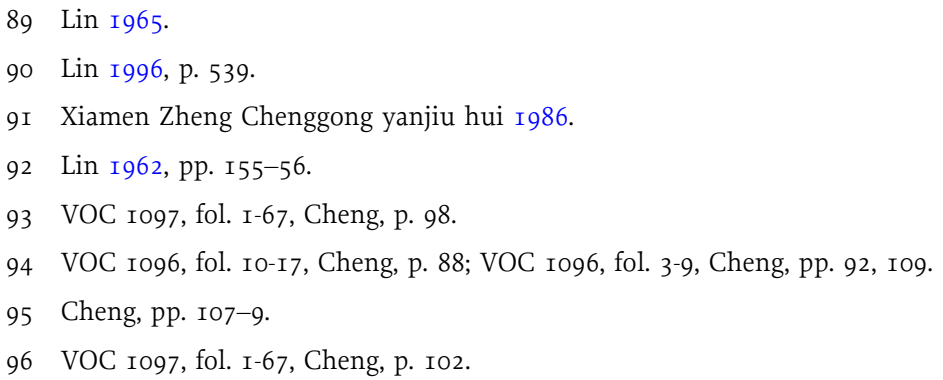


to join forces with Zhilong. The Dutch officials in the company surmised: "We should choose our trade partner seriously and cautiously. We will stand with the Chinese high official and drive out the pirates together." 97 Hence, the dissension and integration of the pirates reveals the fundamental truth about the kou - that it is a loaded term. The characteristics of the term, namely its mobility, instability, and its quick regeneration, can be explained by the fact that many people there existed outside the control of governmental power or in the borders beyond, a situation caused by an ineffective registration system and an unstable border region.

The Ming-Qing transition did not help Dutch expansion, but did help confirm an original "borderless" region as a new local dominant area with clear borders: land mainly centered on south Fujian and Taiwan, and the broad basin of the South and East China Sea. $9^{8}$ When the Ming dynasty fell, the Dutch reported in I642 that China was in chaos and merchants had lost a great deal.99 However, Zhilong still had substantial commodities. ${ }^{\text {Ioo }}$ Though the Dutch defeated and expelled the Spaniards in North Taiwan in 1642, they could not achieve a decisive victory in the Philippines War during I645 to I647. As Haicheng was gradually replaced by Anhai, junks in Anhai could be guided where to go, and so Manila and Dayuan needed to compete. Although Anhai was destroyed by the Manchu army in 1647, with the collapse of the Ming and the ascendance of the Qing, the prosperity of Anhai did not stop during the change of dynasty. ${ }^{\text {Ior }}$ Over the next two decades Zhilong's son Koxinga persisted in fighting against the Manchu power, and his troops wandered around the South China Sea. He found it was hard to survive without a base, so he decided to seize Taiwan. As is generally known, Koxinga defeated the Dutch, forcing them to give up Taiwan. After Zheng built a Chinese regime in Taiwan, he also found that it was necessary to seize Manila to establish another anti-Manchu "fort," causing the Spaniards in the Philippines deep distress. ${ }^{\text {IO2 }}$ Luckily for the Spaniard colonists, Koxinga died suddenly, at the age of thirty-eight and before he could pursue his ambition of taking over Manila. However, the resulting situation was brutal for the mobile people as well as for the borderless people, as many of them were suspected, expelled, or killed.

The conflicts between Lin Feng and the Spaniards, the Spaniards and the Dutch, Koxinga and the Dutch, and Koxinga and the Spaniards reflect the process of border and discourse creation. From the perspective of Lin Feng, the military pressure, whether from the Ming court or the Spaniards, forced him to flee to another region to rule and lead the pirates and commoners. From Zhilong's perspective, the new border created by the Dutch was invalid, as was the border enforced by the Ming empire; he only recognized these borders when it was to his benefit, while Koxinga had his own agenda to create a

97 Ibid.; VOC I I02, fol. I-25, Cheng, pp. I00, II4.

98 For the disruption and chaos caused to local society by the Ming-Qing transition in terms of piracy and the insufficiency in administrative control, see Spence and Wills I979; Struve I984.

99 VOC II38, fol. I-II6, Cheng, p. 235.

Ioo "Iquan (Zheng Zhilong) still transferred considerable amounts of commodities to Manila." See VOC I I42, fol. I-79, Cheng, p. 25 I.

IOI VOCiI59, fol. I-62, Cheng, p. 280. Chen 20I7, pp. 86-I26.

I02 Lee I998, pp. 29-59. 
region with borders to save the Ming and get revenge on the Qing. Hence, he sacrificed his competitor, the Dutch, in order to get control of Dayuan as a base. The integrated borderless people then confirmed south Taiwan as their border with the Spanish colonial power, and the southeast coastline as their border with the Manchus.

\section{REGIONAL BARRIERS AND THE SPACE OF THE BORDERLESS PEOPLE}

In every significant area barriers exist: the inner regional barriers of the Chinese empire (especially the three southeast provinces in this article); the barrier between Zheng's Fujian (mainland) and Taiwan (island); the barrier between the native Taiwanese and the Dutch; the south and north political barrier of Taiwan under Dutch and Spanish dominance; the Manila inner and outer city barrier; the political barrier between the colonial metropole (Manila), the northern region (Pangasian) and southern region (Mindanao) of the Philippines. Among these barriers, the least obvious one was the inexactness of the inner barriers between the three southeast provinces of the Chinese empire.

Relying on the administrative barriers, people who lived on the borders beyond could continue doing their business. The mid-Ming scholar-official Zhao Mingke 趙鳴珂 had once observed that the activities of the bandits were interprovincial. He expressed this opinion by saying that, "The bandits collude across the provinces: Fujian's bandits come to Gaozhou and Chaozhou prefectures in Guangdong to build junks, and go to Ningbo and Shaoxing in Zhejiang to buy their goods, and then go to foreign areas. Bandits in Zhejiang and Guangdong build their junks and buy their goods in Zhangzhou and Quanzhou prefec-

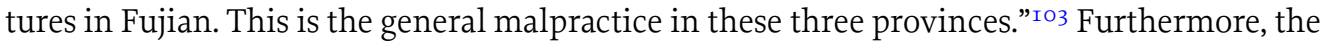
barriers were not simply divided by coastal and inland region. For example, in Fujian, it was recorded that, "The three prefectures, Fuzhou, Xinghua and Quanzhou, suffered from bandits from the sea, while Tingzhou and Zhangzhou suffered from bandits on land."I04

If saying that the administrative barriers were obvious, the cultural and political barriers inside the empire under the new strengthening borders were not obvious. Few people noticed that the bandits constituted by the local populace robbed each other's neighborhoods. We can take Zhangzhou prefecture and Chaozhou prefecture as a case to better understand such division. These two prefectures are side by side, and each experienced severe unrest. One of the counties belonging to Chaozhou prefecture, Zhuluo 諸羅 county, continued to have cases of unrest. Its local history records that Zhang Lian 張璉, the biggest bandit chief in Raoping 饒平 county, robbed other places and wiped out many villages "without concern or [local] lineage restrictions." the bandits who harassed Zhangzhou came from Chaozhou. ${ }^{\text {I06 }}$ However, a Chaozhou literatus Lin Dachun 林大春 also mentioned that Chaozhou suffered much from bandits from other areas. Chaozhou and some areas of Jiangxi province feared that bandits from Zhangzhou would come, and "one day suddenly there were bandits coming from the

I03 Zhao, "Guang Fu Zhe bingchuan huishao lun,” quoted in Fu I956, p. II5.

I04 MSL, SZ 503 JJ 40/I I dinghai, p. 83 I I. Xinghua was an inland prefecture, while Zhangzhou was a coastal one. I05 Zhu I962, p. I2I.

I06 Lin I968, p. 769; MSL, SZ 469 JJ 38/2 gengshen, p. 7888. 
northwest and claiming that they were soldiers, but instead were actually bandits from Zhangzhou." ${ }^{\circ}$ 7 The Dapu local history also records:

The bandits rose up from Ping and Jinguan and rebelled in collusion with Zhangpu's bandits. They built forts and camps valley by valley, and robbed Zhangzhou, Quanzhou, Chaozhou, and Jieyang. ${ }^{\text {го8 }}$

This case strongly demonstrates that bandits in these two prefectures were mobile in order to be able to rob, and that they generally did not rob their own local villages, for they were people living on the borders beyond and who followed the original "order," and thus were not true bandits. In other words, they were closely connected to their local villages. The inner barriers of the empire also stimulated local militarization. Each locality had its own militia, the "village soldiers." These groups were used not only as a defence against outside bandits, but also at times even against the official military. It is not hard to find inscriptions describing how the militia defeated the pirates. ${ }^{\text {Iog }}$ These local militia were found "sufficient to be relied on," I ro so much so that the official military could not threaten the local village. ${ }^{\text {II }}$ As Lin mentioned in his report, the official military was so corrupt that Zhejiang soldiers came to Fujian and "fiercely harassed the Haicheng people, who suffered much pain.” ${ }^{\text {I2 }}$ The same was true for the Guangdong soldiers, who went to Fujian. ${ }^{\text {II } 3}$ In fact, soldiers often joined the bandits, especially after they were dismissed. This was an easy transition considering that many of the soldiers and bandits came from the same villages. There was a famous case in which the soldiers secretly made a deal with encircled bandits in Xiaoyingfang 小營房 in Songjiang Prefecture to let them go by pretending that the bandits had defeated them. "Many Zhangzhou people were the bandits, hence how is it possible not to succeed by using the Zhangzhou soldiers to exterminate the bandits?"II4 Likewise, the similar nature of the bandits and soldiers was clear: be mobile in order to rob.

The best way to solve the problem of the borderless people was to force them to return home and become registered people, fixing them inside the strengthening borders that the empire was establishing. This strategy can be seen in the following incident: "Ruan E 阮鶚 (I509-I567), the Grand Coordinator at that time, led his army to defeat the wokou, but the wokou escaped to the island of Nan'ao 南澳 [in Guangdong]; rebels joined them, making nearly ten thousand families. Some asked Ruan to slaughter the bandits and rebelling families ..., but Ruan said: 'They were bandits in Zhejiang, but after they returned to Meiling [in Fujian], they were ordinary people, why should we kill them all?'”I5 This episode

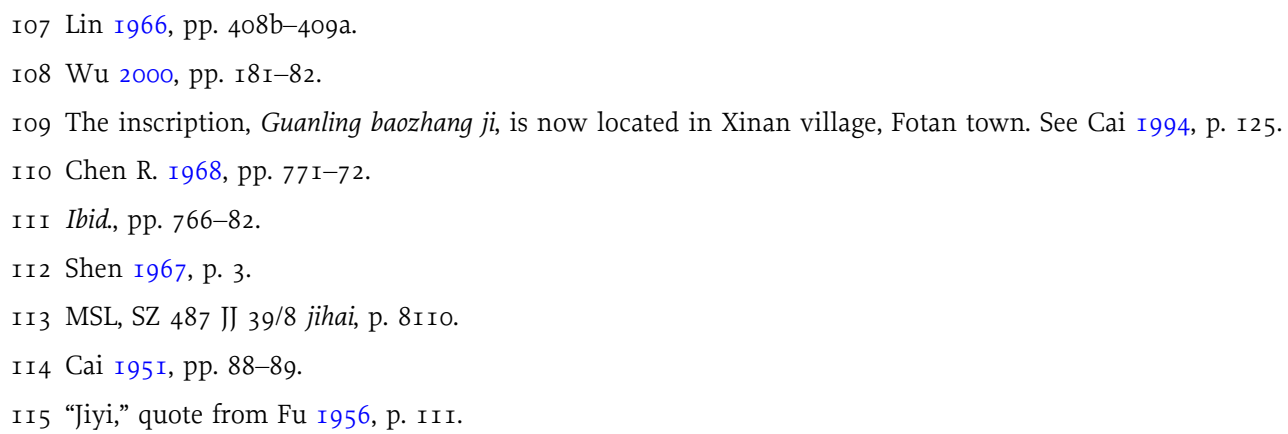


clearly shows that once the mobile people returned to their former status-that of supposedly controlled, registered people-they were not viewed as wokou or haikou. Those who remained mobile, though, were viewed as bandits or pirates. There were many people who could be classified as being outside governance, and, unless an effective registration system were put in place, or unless they were under the agenda of the empire, they and the unrest they brought would never be eliminated.

One study concludes that, "In the latter Ming, the court began using a system of conscription, and enforced the protection of the coast by using both official forces and the citizenry. As the enemies were won over as friends, the kou were finally pacified." I 6 According to Chen Boyi's studies on the Ming military systems, militia, conscription and military strategies, the military reform and its effectiveness are temporary, and effectiveness was more proper to the Nanzhili region and Zhejiang province, but fitted the situation of Guangdong and Fujian provinces rather less. ${ }^{117}$ The regional barriers among the three southeast provinces show that the transformation of the borders beyond continued despite the strengthening borders.

\section{RESHAPING THE HISTORICAL DISCOURSE WITHIN THE CLEARER BORDERS}

As we have shown above, Chinese society experienced many vicissitudes during the sixteenth and seventeenth centuries, including the collapse of the Ming dynasty and the ascendance of the Qing dynasty. The people and the groups that lived along the southeast coast were, at different times, recognized differently and many of their activities were at times sanctioned and at other times outlawed. The studies of piracy produced in the last fifteen years have fundamentally broken with earlier paradigms: this topic directly relates to how marginal people and society came into the national system, with people's identity being reshaped under the strengthening borders and related discourse.

Both of the discourses on individual and borderless groups were significantly reshaped in the process of border building. Firstly, the definition of certain people at that time began to change, especially wokou and haikou. While it is not easy to clearly distinguish between the wokou and haikou, by looking at a couple of examples, we may be able to gain a greater understanding of the identification. The narrations on Wang Zhi 汪直 and Hong Dizhen 洪 迪珍 described them both as haikou and the heads of wokou. ${ }^{\text {II } 8}$ In the records of the Zhangzhou local history (I56I), Hong Dizhen is listed as the chief of bandits while Hong and Wang were named haikou in the Ming "Veritable Record" (I563). Likewise, Hong and Wang were examples of people with different labels, being called wokou, haikou, and "people out of control" in different texts. Generally speaking, after the late Jiajing period, the term wokou was used less and less while the term haikou was more common. In analyses of the unrest between the thirty-ninth to forty-fifth years of the Jiajing reign (I560-I566), Fujian is described as a place where "bandits and haikou rebelled at the

I 6 Wang 2003, pp. 28-34. Similar point with a general description, also see Zheng 2003, pp. I50-52.

II7 Chen 20II.

I 8 MSL, SZ 525 JJ 42/9 bingshen, p. 8567. 
same time," and then it is recorded that this in fact happened. After the forty-fourth year of the Jiajing reign ( 1565 ) we see the rise of Wu Ping 吳平, one of the major haikou. We can see that bandits, wokou, and haikou are found in the texts in parallel. In short, the haikou were at times under the label of wokou. When the wokou were in the ascendancy, the haikou were also classified as wokou, but when the wokou "disappeared," the haikou moniker reappeared. If we view the maritime forces after the wokou's demise as in fact consisting of the same groups, then the actual "disappearance" of the wokou (now labeled haikou) should have come after the "Great Evacuation," an order that forced people who lived on the southeast coast to move approximately ten to eighteen miles inland in order to eradicate anti-Manchu activities in the early Qing period. ${ }^{\text {II } 9}$ It is obvious that during several decades of the haikou unrest different groups often became integrated. ${ }^{\text {I20 }}$

There were many reasons for the confusion in these terms. One of the most essential reasons was the system of registration. As mentioned above, officials widely extorted and imposed tariffs. Pan Jixun 潘季馴 indicated that, "The ordinary people had no way to appeal, so they had to assemble and became bandits." ${ }^{21}$ He furthermore reports that he renewed the system of registration and everything went well. In this case we can see that it was the imposition of the system of control that changed local society as well as enforced the administrative border. ${ }^{122}$ Without such an adjustment, the kou would rise once more. The transformation of the use of the terms wokou and haikou seems to have occurred nearly around Qi Jiguang's victory-he came to Zhangzhou to conquer the haikou, then pursued Wu Ping and killed many haikou. But the record further states that "in wiping out wokou and bandits, Jiguang's contribution was great.” 23 In the Tianqi reign (I62I-I627), we again see the rise of haikou. This phenomenon is closely related to the imposition of land tax. Such measures led to instability and a greater amount of activity outside official control. Those involved in such activity were referred to as haikou. The Dutch also originally used this term to refer to these peoples. Many years later, after the Dutch and Zhilong formed contracts, the same people became merchants. The haikou were active until the end of the Ming dynasty. ${ }^{\text {2 }}{ }^{24}$

Since the government did not have a reliable system for registration, there were numerous people who were considered outside governance; "Even Fujian, a territory of China, is harder to manage than places outside the country." 25 At the same time, soldiers and bandits easily exchanged identities. Feng Jiahui 馮嘉會 (?-I627), Minister of the Ministry of War, indicated that "Fujian used to be afraid of foreigners, but now was afraid of the bandits; we were initially afraid that different bandit groups would join together, but we now fear that bandits and the people, or even soldiers, would join together." ${ }^{26}$ The concern was

\footnotetext{
II9 Chen 200I, pp. I03-4.

I20 Andrade 2005 .

I 2 I MSL, SZ 492 JJ 40/I gengyin, p. 8I8I.

I 22 Liang I989, pp. 34-89.

I23 “Minghuan zhi," in Chen R. I968, pp. I029-30.

I24 Lin I965, pp. 8-I 2 .

I 25 Chen I963, p. I5. See also Academia Sinica I95I, t. I, p. 2.

I 26 MSL, XZ 78 TQ 6/I I wuxu, p. 3796.
} 
that if the haikou could not be controlled, they would cause so much disorder that they would eventually topple the regime.

On the basis of analyzing the various appellations applied to groups at different times, I argue that we should comprehend labels such as wokou and haikou as often referring to the same peoples. The terms used to designate these peoples not only describe these so named, but also reflect those doing the naming. Whether these groups were involved in piracy, trade, or even "daily lives” depends on one's perspective. By analyzing the various kou of different periods, we can see how different labels were applied in different situations, and why the empire and colonizers did that. Through a cursory analysis of these terms and groups, we can see that their activities of piracy and trade are actually two sides of the same coin. It was finally after the "Great Evacuation" that various kou really "disappeared" (at least for over a century), for the whole structure and the complex relationships within coastal society had then changed. The Qing regime finally had a solid registration system, and the borders were enforced. Unrest and trade are topics of interest for scholars, but they are often viewed as being in contrast. Actually, pirates and merchants often existed simultaneously and within homogeneous groups with similar backgrounds. The activities of the coastal groups discussed in this article show us how these groups formed. No matter how the labels changed, the groups and the peoples constituting them did not change. After these groups returned to the places they were supposed to be in, to the lands along the coasts inside the designed or assumed borders, there was no need to label them bandits or pirates any more, for they were then registered people.

Secondly, the new border also brought and enforced a new historical consciousness. The events caused by people such as Lin Feng and Zheng Chenggong that unfolded in this region are consequential to the formation and perceptions of modern nations. The ideas and perceptions owned by today's countries are rooted in historical processes. While the Spaniards successfully secured the Philippines by defeating the merchant-pirates, the Dutch failed to do the same in Taiwan. This difference is critical in helping to explain why twenty-first century perceptions of Taiwan are so closely tied to China, while perceptions of the Philippines are not, despite both territories once having a similar historical status. The Spaniards kept Manila and ruled the Philippines, so the Philippines were assigned the historical explanation of colonial history after it won independence from America, and are involved in a broader historical sense of the Malay archipelago; on the other hand, the Dutch lost and Taiwan was taken by Zheng. A Chinese regime was built and a Chinese historical explanation was made, thus the place became "part of China." Zheng commanded greater military force than Lin, so his relative success was not by pure chance. But the diverging outcome from Zheng versus Lin's conquests is somehow historically pivotal, and the subsequent trajectories of each territory reinforced the outcome. The Manchu emperor had to fight the anti-Qing military in Taiwan, and finally his army was victorious. There were many debates at court over whether it was necessary to leave people and the administrative system in Taiwan. The final decision was not taken based on the land consideration but in the interests of security: if no one lived there, the island would be taken by the pirates again and would constitute a serious threat to the Qing Empire. So the Qing court kept Taiwan as an administrative region and the "hedgerow" of the empire. If the Philippine islands had also been controlled by Zheng's regime, or that control challenged by other "pirates," the Qing court most definitely could not have been able to withstand its 
anti-Qing neighbors. ${ }^{\mathrm{I} 27}$ That was the real reinforced trajectory meaning of those two piratical cases. Few people consider that these two such "different" places had once been so similar and could have had the same fate. However, except for thinking about the occasional and necessary history, historians have a duty to learn more about what really shapes people's identity and historical consciousness.

\section{CONCLUSION}

All in all, the division of the borders and the borders beyond supplied a broad stage for the people in these vaguely defined areas to play different roles. Great powers clashed and redefined their borders within which people became naturalized. It might seem a rather sad story that eventually most of these people submitted themselves to one state or another, but it was never a one-way process. The anthropologist James C. Scott has pointed out how the people in Zomia, a mountainous region including Southwest China, Northeast India, and upland Indochina, lived without being governed by any state. ${ }^{\mathrm{I} 28}$ Whereas Scott concerns himself with those stateless people who searched for self-determination in an anarchic way, I focus more on how the non-stateless peoples lived in the borders beyond, claimed their own order in their own way, and worked and became naturalized (or, were to a greater or lesser extent classified and led) inside the strengthening borders of pre-modern societies. If Scott is good at showing what the state fails to do in marginal areas, this article shows what the powers succeed in doing, and to whom the state has done it. In short, all the disorder and registration or other efforts to establish the management of people inside and beyond the border only proved that the society created its own "order."

\section{REFERENCES}

\section{Primary sources}

Academia Sinica I95I

Academia Sinica ed. Ming-Qing shiliao dingbian 明清史料丁編 (The Fourth Volume of Ming-Qing Historical Document), tome I. Taipei: Academia Sinica, I95I.

Agustín I975

Agustín Gaspar de San. O. S. A. Conquistas de las Islas Filipinas (1565-I6I5). Madrid: Consejo Superior de Investigaciones Cientificas, I975, Libro 2, Capítulo XVI, pp. 40I-5; Capítulo XXI, p. 435.

Alvarez I930

Alvarez Fr. Jose Maria. O. P. Formosa: Geográfica e Históricamente Considerada. Barcelona: Luis Gili, I930.

Borao 200I-2002

Borao José Eugenio. Spaniards in Taiwan: Documents. Taipei: SMC Pub, 200I-2002.

Borao I994

Borao José Eugenio. "Spanish Sources for the History of Taiwan." In Taiwan shiliao guoji xueshu yantao hui lunwenji 臺灣史料國際學術討論會論文集 (Proceedings of International Academic Conference of Taiwan Historical Sources). Taipei: Guoli Taiwan daxue lishixue xi, I994, pp. 37-47.

I 27 Thanks to Jonathan Chu for reminding me that this is also the logic behind the need for empires to continually expand: there are two ways the government can guarantee security against "marginal" groups or the "barbarians," to expand and rule over the ungoverned space or to make a contract with a power that is strong enough to deal with threats or maintain order. About the Qing administrative efforts in Taiwan, refer to Shepherd I993; Chan I998.

I28 Scott 2009 . 


\section{Boxer I953}

Boxer Charles R., ed. South China in the Sixteenth Century. London: Hakluyt Society, I953. [Chinese version: He Gaoji trans. Beijing: Zhonghua shuju, I990.]

Cai I95I

Cai Jiude 采九德. Wobian shilüe 倭變事略 (A Brief Record of Wokou Turmoil). Shanghai: Shanghai shenzhou guoguangshe, I95I.

Cai 1994

Cai Sicong et al. Guanling baozhang ji 官嶺保障記 (1634) (The Inscription of Safeguard Record in Guanling). In Wang Wenjing 王文径 ed., Zhangpu lidai beike 漳浦歷代碑刻 (The Inscriptions of Zhangpu County through the Ages). Zhangpu: Zhangpu xian bowu guan, I994. [Author fieldwork re-correction]

Chen I963

Chen Jin 陳錦. “Zhe-Min zongdu Chen Jin zouben” 浙閩總督陳錦奏本 (A Memorial to the Throne by Zhejiang and Fujian Governor Chen Jin). In Zhengshi shiliao xubian 鄭氏史料續編 (Historical Materials of the Zheng Regime, Continued) I2, TWWXCK I68, I963.

Chen R. I968

Chen Ruxian 陳汝咸 et al., eds. “Minghuan zhi” 名宦志 (Essays of the Famous Officials). In Zhangpu xianzhi 漳 浦縣志 (Gazetteer of Zhangpu County) I4. Taipei: Chengwen chubanshe, I968.

Chen Y. I968

Chen Ying 陳瑛 et al., eds. Haicheng xianzhi 海澄縣志 (Qianlong) (The Gazetteer of Haicheng County). Taipei: Chenwen chubanshe, I968.

Gao I 962

Gao Gong 高拱. “Yu Yin Shiting lun wozei” 與殷石汀論倭賊 (Discussing the Wo Bandits with Yin Shiting). In Gao wenxiang gong wenji 高文裏公文集 (Collected Works of Gao the Literate and Victorious Gentleman), MJSWB 302.

$\mathrm{Gu} 1977$

Gu Yingtai 谷應泰. “Yanhai woluan” 沿海倭亂 (The Coastal Wo Unrest), Mingshi jishi benmo 明史紀事本末 (A Topical History of the Ming Dynasty) 55. Beijing: Zhonghua shuju, I977, tome 3.

Hudson I96I

Hudson G. F. Europe and China: A Survey of Their Relations from the Earliest Times to I800. Boston: Beacon Press, I96I. [Chinese version: Li Shen et al., trans. Beijing: Zhonghua shuju, 2004.]

Jiang 1962

Jiang Bao 姜寶. “Yi fang wo” 議防倭 (A Discussion of Keeping Wo Away), Jiang Feng'e ji 姜鳳阿集 (Collected Works of Jiang Feng'e), MJSWB 383.

Lee 2008

Lee Yu-chung 李毓中 ed. Taiwan yu Xibanya guanxi shiliao huibian 臺灣與西班牙關係史料彙編 (The Historical Sources Collection of Taiwan-Spain Relationships) (I). Nantou: Guoshi guan Taiwan wenxian guan, 2008.

Lin 1966

Lin Dachun 林大春. “Chaozhou fu tongpan Weng gong ping kou bei” 潮州府通判翁公平寇碑 (The Pacifying Bandits Inscription by Assistant Prefect Mr. Weng of the Chaozhou Prefecture), see Chaoyang xianzhi 潮陽縣志 (Guangxu) (Gazetteer of Chaoyang County) 20. Taipei: Chengwen chubanshe, I966, pp. 408b-409a.

Lin 1965

Lin Shengwu 林繩武 ed. “Minhai haikou shimoji,” 閩海海寇始末. In Haibin dashiji 海濱大事記 (Records of Big Events on Coastal Areas), TWWXCK 213, I965.

Lin 1962

Lin Shidui 林時對. “Zheng Zhilong fuzi zusun sanshi ju haidao” 鄭芝龍父子祖孫三世據海島 (Three Generations of Zheng Family's Occupation of the Islands), Hezha congtan 荷牐叢談 (Lotus Alliance Serials) 4, TWWXCK I53, I962, pp. I55-56.

Lin 1996

Lin Xiyuan 林希元. “Yu Weng Jianyu biejia shu” 與翁見愚別駕書 (Letter to Department Assistant Magistrate Weng Jianyu). In Lin Ciya xiansheng wenji 林次崖先生文集 (Collected Works of Mr. Lin Ciya) 5, collected in Siku quanshu cunmu congshu, Jibu 四庫全書存目叢書 - 集部 (Series of Books Catalogued in Emperor's Four Treasures, "Collections") 75. Jinan: Qilu shushe, I996.

Lin 1968

Lin Xiechun 林偕春. “Bingfang zonglun” 兵防總論 (General Principles of Military Defense). In Zhangpu xianzhi 漳浦縣志 (Kangxi) (Gazetteer of Zhangpu County). Taibei: Chenwen chubanshe, rg68. 
Ma 1985

Ma Kun 馬坤. “Lun wo shulüe” 論倭疏略 (A Brief Memorial of Wo). In Chen Menglei 陳夢雷 ed., Gujin tushu jicheng 古今圖書集成 (Complete Collection of Illustrations and Writings from the Earliest to Current Times), p. 2I2. Beijing: Zhonghua shuju; Chengdu: Bashu shushe, I985.

Mao I 962

Mao Kun 茅坤. “Tiaoshang Li Jiquan zhongcheng haikou shiyi” 條上李汲泉中丞海寇事宜 (Respective Memorials of the Affairs of Pirates to Grand Coordinator Li Jiqua). In Mao Lumen wenji 茅鹿門文集 (Collected Works of Mao Lumen), MJSWB 256, p. 2700 .

Mendoza I953

Mendoza, J. G. de. The History of the Great and Mighty Kingdom of China and the Situation Thereof. S. G. T. Staunton ed., London: Hakluyt Society, I853. [Chinese version: He Gaoji trans. Beijing: Zhonghua shuju, I998].

MJSWB

MJSWB: Ming Jingshi wenbian 明經世文編 (A Collection of Memorials on Statecraft from the Ming Dynasty). Beijing: Zhonghua shuju, I962.

MSL I 962

MSL: Ming Shilu 明實錄 (Ming Veritable Records) (References to MSL are in the form: reign name, volume, reign title and year [date in Chinese calendar], page number). Taipei: Academia Sinica, I962. SZ: Shizong shilu 世宗實錄; XZ: Xizong shilu 喜宗實錄.

Shen 1967

Shen Dingjun 沈定鈞 et al. “Bingji” 兵紀 (Military Records). In Zhangzhou fuzhi xuanlu 漳州府志選錄 (Selected Records of the Gazetteer of Zhangzhou Prefecture), TWWXCK 232, I967.

TPI

TPI: Blair, Emma, Helen James Alexander Robertson, and Edward Gaylord Bourne, eds., The Philippine Islands, 1493-1803: Explorations by Early Navigators, Descriptions of the Islands and Their Peoples, Their History and Records of the Catholic Missions, as Related in Contemporaneous Books and Manuscripts, Showing the Political, Economic, Commercial and Religious Conditions of Those Islands from Their Earliest Relations with European Nations to the Beginning of the Nineteenth Century. Cleveland, OH: A.H. Clark Co., I903-I909.

Tu 1962

Tu Zhonglü 屠仲律. “Yuwo wushi shu” 禦倭五事疏 (Fifty Memorials about Defending against Wo). In Tu Shiyu zoushu 屠侍御奏疏 (The Memorials of Attendant Censor Tu), MJSWB 282.

TWWXCK

TWWXCK: Taiwan wenxian congkan 臺灣文獻叢刊 (Collection of Reprints of Taiwan Documents). Taipei: Taiwan yinhang jingji yanjiu shi, I957-I972.

Villalobos I903-I909

Villalobos Ruy López de, et al. "Expedition of Ruy López de Villalobos, I54 I-46" (Translated and synopsized by James A. Robertson, from Col. doc. inéd., as follows: Ultramar, ii, part i, pp. I-94; Amér. y Oceania, pp. I I7-209, and xiv, pp. I5I-65), in TPI vol. II (I52 I-I569), pp. 45-76.

VOC

VOC (Vereenigde Oost-Indische Compagnie)-Taiwan section: Cheng Shaogang 程紹剛 annotates and translates. Helan ren zai Fuermosha 荷蘭人在福爾摩莎 (The Dutch in Formosa) ("De VOC en Formosa I624-I662: Een Vergeten Geschiedenis.” Ph.D. dissertation, Universiteit Leiden, I995). Taipei: Linking Publishing Press, 2000. [Somehow more original than De Dagregisters van het Kasteel Zeelandia (The Zeelandia Diaries) since it was not compiled and edited as a brief report to Batavia.]

Wang I940

Wang Poleng 王婆楞. Lidai zheng wo wenxian kao 歷代征倭文獻考 (The Evidential Studies of Documents about Expedition to Wo during the Past Dynasties). Chongqing: Zhengzhong shuju, I940.

Witt 1626

Witt Gerrit Fredricxz de. "Letter from Gerrit Fredricxz de Witt to Governor-General Pieter de Carpentier," I5 November I626, VOC I090: I96-206, fol. 202.

Wu 2000

Wu Lisi 吴立思 ed. “Zazhi: kouzei” 杂志・寇贼 (Miscellaneous Essays: Bandits). In Dapu xianzhi 大埔县志 (Gazetteer of Dapu County). Dapu: Dapu County Local Documentary Office, 2000.

Wu 1934

Wu Yunian 吳玉年. “Mingdai wokou shiji zhimu” 明代倭寇史籍志目 (A Compilatory and Continued Catalogue of Historical Documents about Wokou in the Ming Dynasty). Yugong banyue kan (Yugong Biweekly Journal) $2.4 \& 2.6$ (I934), pp. 29; 27. 
Xiamen Zheng Chenggong yanjiu hui I986

Xiamen Zheng Chenggong yanjiu hui 厦门郑成功研究会 and Xiamen Zheng Chenggong jinian guan 厦门郑 成功纪念馆, ed. Zheng Chenggong zupu sanzhong 郑成功族谱三种 (Three Genealogies of Zheng Chenggong). Fujian: Fujian renmin chubanshe, I986.

Xu I962

Xu Fuyuan 許孚遠. “Shutong haijin shu” 疏通海禁疏 (Memorials on Loosening the Maritime Prohibition). In Jinghe tang ji 敬和堂集 (Works of the Respectful and Harmonious Hall), MJSWB 400.

Yan 2000

Yan Congjian 嚴從簡. Shuyu Zhouzi lu 殊域周咨錄 (Informative Records on Countries Far Away). Beijing: Zhonghua shuju, 2000.

Ye 1962

Ye Xianggao 葉向高. Cangxia zhengxuji 蒼霞正續集 (Cangxia Compilatory and Continued Works), MJSWB 46r.

Zhang 1974

Zhang Tingyu 張廷玉 et al., eds. “Zhu Wan liezhuan” 朱紈列傳 (Biographies of Zhu Wan), Mingshi 明史 (History of Ming) 205. Beijing: Zhonghua shuju, I974.

Zhang I98I

Zhang Xie 張奒. Dong xi yang kao 東西洋考 (Research on the Eastern and Western Oceans). Xie Fang Annotates. Beijing: Zhonghua shuju, I98I.

Zhangzhou fuzhi

Zhangzhou fuzhi 漳州府志 (Gazetteer of Zhangzhou Prefecture) (Guangxu) 46, “Jiyi” 紀遺 (Records of the Omission), quote from $\mathrm{Fu}$ I956.

Zhao I962

Zhao Bingran 趙炳然. Zhao Gongxiang wenji 趙恭襄文集 (Collected Works of Zhao the Respectful and Victorious Gentleman), MJSWB 253.

Zheng I988

Zheng Liangsheng 鄭梁生. “Zhongguo difangzhi zhong de wokou shiliao” 中國地方志中的倭寇史料 (Historical Materials of Wokou in the Chinese Gazetteers). Hai jiao shi yanjiu (Maritime History Studies) I4.2 (I988), pp. 75-86.

Zheng 1987

Zheng Liangsheng 鄭梁生. Mingdai wokou shiliao 明代倭寇史料 (Historical Materials of Wokou in the Ming Dynasty). Taipei: Wenshi chubanshe, I987.

Zheng I985

Zheng Liangsheng 鄭梁生. Mingshi Riben zhuan buzheng 明史日本傳補正 (Supplementary Studies of Essays on Japan in the History of Ming). Taipei: Wenshi chubanshe, I985.

Zheng I990

Zheng Ruozeng 鄭若曾. “Kai hushi,”開互市. In Chouhai tubian 籌海圖編 (Compilation Atlas about the Maritime Affairs), collected in Zhongguo bingshu jicheng 中国兵书集成 (Collection of Chinese Military Writings). Beijing: Jiefangjun chubanshe; Shenyang: Liaoning shushe, I990, tome I5.

Zheng I988

Zheng Xiao 鄭曉. Wu xue bia<n 吾學編 (A Compilation of My Studies). Beijing: Shumu wenxian chubanshe, I988.

Zhou I935

Zhou Xuanwei 周玄暐. Jinglin xuji 涇林續記 (Continued Records of Jing Woods). In Wang Yunwu 王雲五 ed., Congshu jicheng chubian 叢書集成初編 (Complete Collection of Books from Various Collectanea). Shanghai: Shangwu yinshuguan, I935, No. 2954(2).

Zhou I962

Zhou Zhongxuan 周鍾瑄 et al., eds. “Shuilu fangxun” 水陸防汛 (Affairs of Defending from Land and Sea), Zhuluo xianzhi 諸羅縣志 (Gazetteer of Zhuluo County), TWWXCK I4I, I962.

Zhu I962

Zhu Wan 朱紈. “Yueshi haifang shi” 閱視海防事 (Issues of the Inspection of Coastal Defense). In Zhu zhongcheng piyu ji 朱中丞璧餘集 (Brick-Remaining Collected Works of the Grand Coordinator Zhu), MJSWB 205.

\section{Secondary sources}

Andrade 2013

Andrade, Tonio. Lost Colony: The Untold Story of China's First Great Victory over the West. New Jersey: Princeton University Press, 2013. 
Andrade 2008

Andrade, Tonio. How Taiwan Became Chinese: Dutch, Spanish, and Han Colonization in the Seventeenth Century. New York: Columbia University Press. 2008.

Andrade 2005

Andrade, Tonio. "The Company's Chinese Pirates: How the Dutch East India Company Tried to Lead a Coalition of Pirates to War against China, I62 I-I662." Journal of World History I5.4 (2005), pp. 4I5-44.

Antony 2003

Antony, Robert J. Like Froth Floating on the Sea: The World of Pirates and Seafarers in Late Imperial South China. Berkeley: Institute of East Asian Studies, 2003.

Arano 2005

Arano, Yasunori 荒野 泰典. “The Formation of a Japanocentric World Order.” International Journal of Asian Studies 2.2 (2005), pp. I85-26I.

Bao I968

Bao Zunpeng 包遵彭 ed. Mingdai guoji maoyi 明代國際貿易 (The International Trade of Ming Dynasty). Taipei: Taiwan xuesheng shuju, I968.

Bianco I 962

Bianco, Lucien. “Classes Laborieuses et Classes Dangereuses dans la Chine Impériale au XIXe Siècle.” Annales: Economies, Sociétés et Civilisations i7:6 (I962), pp. II75-I I82.

Blussé I997

Blussé, Leonard. Badaweiya huaren yu Zhong-He maoyi 巴达维亚华人与中荷贸易 (The Chinese in Batavia and Sino-Dutch trade). Nanning: Guangxi renmin chubanshe, I997.

Blussé I98I

Blussé, Leonard. "Batavia, I6I9-I740: The Rise and Fall of a Chinese Colonial Town." Journal of Southeast Asian Studies I2:I (I98I), pp. I59-78.

Blussé 1977

Blussé, Leonard. “Inpo, Chinese Merchant in Pattani: A Study in Early Dutch-Chinese Relations.” In Proceedings of the Seventh IAHA Conference, ed. William Warren, Pensri Duke and Prapin Manomaivibool, pp. 290-309. Bangkok: Chulalongkorn University Press, I977.

Brook 2013

Brook, Timothy. Mr. Selden's Map of China: Decoding the Secrets of a Vanished Cartographer. Toronto: House of Anansi Press, 2013.

Chan 1998

Chan Su-chuan 詹素娟. "Zuqun, lishi yu diyu—Gamanlan ren de lishi bianqian (cong shiqian dao I9oo nian) 族群、歷史與地域——噶瑪蘭人的歷史變遷（從史前到 1900 年） (Ethnics, History, and Region: The Historical Transformation of the Kavalan People, from Pre-history to I900).” Ph.D. dissertation, National Taiwan Normal University, I998.

Chaunu I960

Chaunu, Pierre. Les Philippines et le Pacifique des Ibériques (XVIe, XVIIe, XVIIIe Siècles): Introduction Méthodologique et Indices d'Activité. Paris: S. E. V. P. E. N., I960.

Chen 2017

Chen Boyi 陈博翼. “Cong Yuegang dao Anhai: Fan haikou zhixu yu Xi-He chongtu beijing xia de gangkou zhuanyi” 从月港到安海: 泛海寇秩序与西荷冲突背景下的港口转移 (From Yuegang to Anhai: Port Transfer in the Context of Pan-Piracy Order and Spanish-Dutch Conflict, I550-I650). Quanqiu shi pinglun (Global History Review) I2 (20I7), pp. 86-I26.

Chen 20II

Chen Boyi 陈博翼. “Mingdai Nanzhili haifang yanjiu 明代南直隶海防研究 (Coastal Defense of Nanzhili Region in Ming China).” Masters Thesis, Peking University, 20 I I.

Chen 2009a

Chen Boyi 陈博翼. “Aytiur (Aytim) diming shizheng: fulun zaoqi Haicheng de dui Fei maoyi” Aytiur (Aytim) 地名釋證: 附論早期海澄的對菲貿易 (Where Is the Port of Aytiur (Aytim): Transliteration, Location and Early Commercial Trade with the Philippines). Mingdai yanjiu (Journal of Ming Studies) I 3 (2009), pp. 8I-I08

Chen $2009 b$

Chen Boyi 陈博翼. “Shiliu dao shiqi shiji Zhongguo dongnan luhai dongluan he maoyi suo jian de 'kou”" I6-I7 世纪中国东南陆海动乱和贸易所见的 “寇” (Disturbance of Trade: 'Kou’ in the Southeastern Coastal Region of China, I6th-17th Century). Kaikō toshi kenkyu (Journal of Port Cities Studies) 4 (2009), pp. 3-24. 
Chen $200 \mathrm{I}$

Chen Chunsheng 陈春声. “Cong ‘woluan’ dao ‘qianhai” 从 “倭乱” 到 “迁海” (From the “Unrest of Wokou” to the "Great Evacuation”). In Ming-Qing luncong (Collected Studies of Ming-Qing) 2, ed., Zhu Chengru and Wang Tianyou, pp. 73-Io6. Beijing: Zijingcheng chubanshe, 200I.

Chen I939

Chen Maoheng 陳禁恒. Mingdai wokou kaolüe 明代倭寇考略 (A Brief Evidential Study of Wokou in the Ming Dynasty). Harvard-Yenching Institute, I939.

Chen 1934

Chen Shen 陳慎. “Ming haikou Lin Afeng kao” 明海寇林阿鳳考 (An Evidential Study of the Pirate Lin Afeng in the Ming Dynasty). Dongfang zazhi (Oriental Journal) 3I:7 (I934).

Chen I965

Chen Wenshi 陳文石. “Ming Jiajing nian jian Zhe-Fu yanhai kouluan yu sifan maoyi de guanxi” 明嘉靖年間浙 福沿海寇亂與私販貿易的關係 (The Relations of Unrest and Private Trade at Coastal Zhejiang and Fujian during the Ming Jiajing Reign). Bulletin of the Institute of History and Philology Academia Sinica 36:I (I965), pp. 375-48I.

Cheng 2013

Cheng Weichung. War, Trade and Piracy in the China Seas (I622-I683). Leiden: Brill, 2013.

Chin 2014

Chin, James (Qian Jiang). "A Hokkien Maritime Empire in the East and South China Seas, I620-83." In Persistent Piracy: Maritime Violence and State-Formation in Global Historical Perspective, ed. S. Amirel, L. Müller and Stefan Eklöf Amirell, pp. 93-I I2. London: Palgrave Macmillan, 2014.

Chinese Society for Historians of China's Foreign Relations I987

Chinese Society for Historians of China's Foreign Relations, ed. Zhongwai guanxi shi yicong 中外关系史译丛 (Collected Translations of Sino-Foreign Relations History) 4. Shanghai: Shanghai yiwen chubanshe, I987.

Craig I927

Craig, Austin. Rizal's Life and Minor Writings. Manila: Philippine Education Co., I927.

Cushman I993

Cushman, Jennifer W. Fields from the Sea: Chinese Junk Trade with Siam during the Late Eighteenth and Early Nineteenth Centuries. Ithaca: Cornell Southeast Asia Program Publications, I993.

Dai 1982

Dai Yixuan 戴裔煊. Mingdai Jia-Long jian de wokou haidao yu Zhongguo zibenzhuyi de mengya 明代嘉隆间的倭寇 海盗与中国资本主义的萌芽 (Wokou, Pirates, and the Sprouts of Chinese Capitalism during the Jiajing and Longqing Reign of the Ming Dynasty). Beijing: Chinese Social Science Press, I982.

Eskildsen 2005

Eskildsen, Robert. "Of Civilization and Savages: The Mimetic Imperialism of Japan's I874 Expedition to Taiwan.” In Settler Colonialism in the Twentieth Century: Projects, Practices, Legacies, ed. Caroline Elkins and Susan Pedersen, pp. 388-4I8. New York and London: Routledge, 2005.

Eskildsen 2003

Eskildsen, Robert. "Leading the Natives to Civilization: The Colonial Dimension of the Taiwan Expedition." In Edwin O. Reischauer Institute of Japanese Studies Lecture Series. Cambridge, MA: Harvard University, 2003.

Faure 2007

Faure, David. Emperor and Ancestor: State and Lineage in South China. Stanford, CA: Stanford University Press, 2007.

Flynn 2001

Flynn, Dennis O., Arturo Giraldez and James Sobredo, eds. European Entry into the Pacific. Ashgate, $200 \mathrm{I}$.

Fu 1956

Fu Yiling 傅衣凌. Ming-Qing shidai shangren ji shangye ziben 明清时代商人及商业资本 (Merchants and Commercial Capitals in Ming-Qing Times). Beijing: Renmin chubanshe, I956.

Gil 20I I

Gil, Juan. Los Chinos en Manila: Siglos XVI y XVII (The Chinese in Manila: Sixteenth to Seventeenth Centuries). Macau: Centro Científico e Cultural de Macau, 20 I.

Gonzalez I964

Gonzalez, Jose Maria. Histoira de las Misiones Dominicanas de China (I632-I700). Madrid: I964.

Hang 2016

Hang, Xing. Conflict and Commerce in Maritime East Asia: The Zheng Family and the Shaping of the Modern World, c. I620-I720. Cambridge, UK: Cambridge University Press, 2016. 
Ho 2013

Ho, Dahpon David. “The Empire’s Scorched Shore: Coastal China, I633-I683.” Journal of Early Modern History I7 (2013), pp. 53-74.

Hsiao I960

Hsiao, Kung-chuan. Rural China: Imperial Control in the Nineteenth Century. Seattle: University of Washington Press, I960.

Huang I988

Huang Shengzhang 黃盛璋. “Mingdai houqi haijin kaifang hou haiwai maoyi ruogan wenti” 明代后期海禁开 放后海外贸易若干问题 (Several Issues of the Overseas Trade after Rescinding the Sea Prohibition in the Later Ming). Haijiao shi yanjiu (Maritime History Studies) I3:I (I988).

Hucker I97 I

Hucker, Charles O. Two Studies on Ming History. Ann Arbor: Center for Chinese Studies, The University of Michigan, I97I.

Jin I990

Jin Yingxi 金应熙 ed., Feilubin shi 菲律宾史 (History of the Philippines). Zhengzhou: Henan daxye chubanshe, I990.

Katayama I962

Katayama Seijirō 片山 誠二郎. “Gekkō ‘Nijūyonshō’ no hanran”月港「二十四將」の反亂 (On the Riot of “the Twenty-four Leaders” at Yuegang). In Shimizu Hakushi tsuito kinen Mindai shi ronsō 清水博士追悼記念明代史論 叢 (Studies on the Ming period, presented to Dr. Shimizu), pp. 389-420. Tokyo: Daian, I962.

Katayama I953

Katayama Seijirō 片山 誠二郎. “Mindai kaijō mitsu-bōeki to enkai chihō kyōshinsō” 明代海上密貿易と沿海 地方郷紳層 (Maritime Private Trade and the Coastal Gentry Class in the Ming Dynasty). Rekishigaku kenkyu (Historical Studies) I64 (I953), pp. 23-32.

Kuhn I970

Kuhn, Philip. Rebellion and its Enemies in Late Imperial China: Militarization and Social Structure, I796-I864. Cambridge, MA: Harvard University Press, I970.

Lai 1954

Lai Yung-hsiang 賴永祥. “Ming Zheng zheng Fei qitu” 明鄭征菲企圖 (The Attempt of Conquering the Philippines from Ming Koxinga). Taiwan fengwu (The Taiwan Folkways) 4:I (I954), pp. I9-20.

Lee 1998

Lee Yu-chung 李毓中. “Ming Zheng yu Xibanya diguo: Zhengshi jiazu yu Feilübin guanxi chutan” 明鄭與西班 牙帝國: 鄭氏家族與菲律賓關係初探 (Zheng Regime of Ming and the Spanish Empire: Exploration on Relations of Zheng Family and the Philippines). Hanxue yanjiu (Chinese Studies) I6.2 (I998), pp. 29-59.

Li I93I

Li Changfu 李長傅. “Feilübin shi shang Limahong zhi zhenren kao bu” 斐律賓史上李馬奔之真人考補遺 (The Supplementary Evidential Studies of the Real Man Limahong in the History of the Philippines). Yanjing xuebao (Yenching Journal of Chinese Studies) 9 (I93I), pp. I869-7I.

Li 1956

Li Guangbi 李光璧. Mingdai yuwo zhanzheng 明代御倭战争 (The Wars of Defending against Wo during the Ming Dynasty). Shanghai: Shanghai renmin chubanshe, I956.

Li I93I

Li Guangming 黎光明. “Feilübin shi shang Li Maben (Limahong) zhi zhenren kao buzheng” 斐律賓史上 “李馬奔” Limahong之真人考補正 (The Supplementary Evidential Studies and Demonstration of the Real Man Li Maben in the History of the Philippines). Yanjing xuebao (Yenching Journal of Chinese Studies) Io (I93I), pp. 206I-8I.

Li 1933

Li Jinhua 李晋華 ed. Sanbai nian qian wohuo kao 三百年前倭禍考 (The Evidential Studies of Wo Disasters Three Hundred Years Ago). Nanjing: Guomin waijiao weiyuanhui, I933.

Liang 1989

Liang Fangzhong 梁方仲. “Yitiaobian fa”一条鞭法 (The Single-Whip Reform). In Liang Fangzhong jingji shi lunwen ji 梁方仲经济史论文集 (Collected Works by Liang Fangzhong in Economic History). Beijing: Zhonghua shuju, I989, pp. 34-89.

Lin 1987

Lin Renchuan. Mingmo Qingchu siren haishang maoyi (The Private Maritime Trade in the Late Ming and Early Qing). Shanghai: East China Normal University Press, I987. 
McCarthy I970

McCarthy, Charles J. “On the Koxinga Threat of I662.” Philippine Studies I8:I (I970), pp. I87-96.

Murai 2005

Murai Shōsuke 村井 章介. Higashi Ajia no naka no Nihon bunka 東アジアのなかの日本文化 (Japanese Culture in East Asia). Tokyo: Hōsō Daigaku Kyōiku Shinkōkai, 2005.

Murray 1987

Murray, Dian H. Pirates of the South China Coast, I790-I8Io. Stanford: Stanford University Press, I987.

Nakajima 2010

Nakajima Gakushō 中島 楽章. “I4-I6 seiki, Higashi Ajia bōeki titujo no henyō to saihen” I4-I6 世紀、東アジ ア貿易秩序の変容と再編 一朝貢体制から1570年システムへ (Transformation and Reorganization of the International Trade Order in East Asia from the I4th to I6th Century: From the Tributary System to the "I570 System"). Shakai keizai shigaku (Socio-Economic History) 76:4 (2010), pp. 3-26.

$\mathrm{Ng} 2017$

Ng Chin-Keong. Boundaries and Beyond: China's Maritime Southeast in Late Imperial Times. Singapore: NUS Press, 2017.

$\mathrm{Ng}$ I983

Ng Chin-Keong. Trade and Society: The Amoy Network on the China Coast, I683-I735. Singapore: Singapore University Press, I983.

Oka 2010

Oka Mihoko 岡 美穂子. Shōnin to senkyōshi: Nanban bōeki no sekai 商人と宣教師: 南蛮貿易の世界 (Merchant and Missionary: World of Nanban Trade). Tokyo: Tōkyō Daigaku Shuppankai, 20 ro.

Prakash 1997

Prakash, Om. European Commercial Expansion in Early Modern Asia. Aldershot: Variorum, I997.

Ptak 2003

Ptak, Roderich. China, the Portuguese, and the Nanyang: Oceans and Routes, Regions and Trade (c.1000-I600). Aldershot and Burlington: Ashgate, 2003

Qian I986

Qian Jiang 钱江. “I570-I760 nian Zhongguo he Lüsong maoyi de fazhan ji maoyi e de gusuan” I570-I760 年中国和吕宋贸易的发展及贸易额的估算 (The Evaluation of the Development and Volume of Trade between China and Luzon during the period I570-1760). Zhongguo shehui jingji shi yanjiu (The Journal of Chinese Social and Economic History) (I986), pp. 69-78.

Rodríguez 2004

Rodríguez, Manel Ollé. "Early Spanish Insertion into Southeast Asia: the Chinese Factor." In Iberians in the Singapore-Melaka Area and Adjacent Regions (I6th to I8th Century), ed. Peter Borschberg, pp. 23-34. Wiesbaden: Harrassowitz Verlag, 2004.

Sa 1937

Sa Shiwu 薩士武. “Ming Chenghua Jiajing jian Fujian shibo si yizhi Fuzhou kao” 明成化嘉靖間福建市舶司移 置福州考 (An Evidential Study of Fujian Maritime Trade Office Relocating in Fuzhou during the Chenghua and Jiajing Reigns in the Ming Dynasty). Yugong banyue kan (Yugong Biweekly Journal) 7:I-3 (I937), pp. 247-50.

Schurz I959

Schurz, W. L. The Manila Galleon. New York: E. P. Dutton \& Co., I 959.

Scott 2009

Scott, James C. The Art of Not Being Governed: An Anarchist History of Upland Southeast Asia. New Haven: Yale University Press, 2009.

See 2013

See, Teresita Ang. “Limahong: Pirate, Rebel or Hero?" In Chinese in the Philippines, Vol. 4. Manila: Kaisa Para Sa Kaunlaran, Inc., 2013, pp. 290-302.

Shen 2005

Shen Dengmiao 沈登苗. “Mingdai wokou yanjiu zhongwen lunzhu tilu 500 zhong ji bianzhu ganyan” 明代倭 寇研究中文论著题录 500 种及编著感言 (Abstracts of 500 Chinese Works about Studies of Wokou in Ming Dynasty and the Reflections of Compilation), originally published on the website of "The Academic Criticism" and then authorized to publish at "Ivory Tower." See: http://xiangyata.net/data/articles/dor/632. html (April I6, 2005).

Shepherd I993

Shepherd, John Robert. Statecraft and Political Economy on the Taiwan Frontier, I600-I800. Stanford, CA: Stanford University Press, I993. 
So I 975

So, Kwan-wai. Japanese Piracy in Ming China during the Sixteenth Century. East Lansing: Michigan State University, I975.

Souza 2004

Souza, George Bryan de. The Survival of Empire: Portuguese Trade and Society in China and the South China Sea, I630-I754. Cambridge, UK: Cambridge University Press, 2004.

Spence and Wills 1979

Spence, Jonathan D., and John E. Wills, Jr., eds. From Ming to Ch'ing: Conquest, Region, and Continuity in Seventeenth Century China. New Haven: Yale University Press, I979.

Struve I 984

Struve, Lynn. The Southern Ming, I644-I662. New Haven: Yale University Press, I984.

Tanaka I96I

Tanaka Takeo 田中 健夫. Wakō to kangō bōeki 倭冦と勘合貿易 (The Japanese Pirate and the Tally Trade). Tokyo: Shibundō, I96r.

Teng 2004

Teng, Emma. Taiwan's Imagined Geography: Chinese Colonial Travel Writing and Pictures, I683-I895. Cambridge, MA: Harvard University Asia Center, 2004.

Ts'ao I979

Ts’ao Yung-ho 曹永和. “Ouzhou gu ditu shang zhi Taiwan” 歐洲古地圖上之臺灣 (Taiwan Shown in the Old European Maps). In Taiwan zaoqi lishi yanjiu 臺灣早期歷史研究 (Research into Early Taiwan History). Taipei: Lianjing, I979, pp. 307-8.

Wakeman I966

Wakeman, Frederic. Strangers at the Gate: Social Disorder in South China, I839-I86I. Berkeley: University of California Press, I966.

Wang 2003

Wang Rigen 王日根. “Mingdai dongnan haifang zhong diwo liliang duibi de bianhua jiqi yingxiang” 明代东南 海防中敌我力量对比的变化及其影响 (The Comparison of the Power Relational Transformation and Influence of the Southeast Coastal Defense in the Ming Dynasty). Zhongguo shehui jingjishi yanjiu (The Journal of Chinese Social and Economic History) 2 (2003), pp. 28-34.

Wills 1998

Wills, Jr., John E. "Relations with Maritime Europeans, I5 I4-I662.” In The Cambridge History of China: Volume 8 , The Ming Dynasty, I368-I644, Part 2, ed. Denis C. Twitchett and Frederick W. Mote, pp. 333-75. New York: Cambridge University Press, I998.

Wu 1999

Wu Daxin 吳大昕. “Ming Jiajing wokou yanjiu huigu” 明嘉靖倭寇研究的回顧 (A Review of Studies of Wokou in the Jiajing Reign of the Ming Dynasty). Mingdai yanjiu tongxun (Association for Ming Studies Newsletter) 2 (I999), pp. 9I-Io6.

Wu 1996

Wu Jianyong 吴建雍. “Qing qianqi Zhongguo yu Badaweiya de fanchuan maoyi” 清前期中国与巴达维亚的帆 船贸易 (The Sailing Trade between China and Batavia in Early Qing). Qingshi yanjiu (Studies in Qing History) 3 (I996), pp. 3I-34.

Wu 1929

Wu Zhonghan 吳重翰. Mingdai wokou fanhua shilüe 明代倭寇犯華史略 (A Brief Introduction of Wokou Invasion in the Ming Dynasty). Shanghai: The Commercial Press, I929.

Xue 1936

Xue Chengqing 薛澄清. “Mingmo Fujian haiguan qingkuang ji qi didian bianqian kaolüe” 明末福建海關情況 及其地點變遷考略 (A Brief and Evidential Study on the Situation of Fujian Customs and Its Location Changing in the Late Ming). Yugong banyue kan (Yugong Biweekly Journal) 5:7 (I936), pp. 43-45.

Zhang I930

Zhang Xinglang 張星烺. “Feilübin shi shang Li Maben (Limahong) zhi zhenren kao” 斐律賓史上 “李馬奔” Limahong 之真人考 (The Evidential Studies of the Real Man Li Maben in the History of the Philippines). Yanjing xuebao (Yenching Journal of Chinese Studies) 8 (I930), pp. I473-83.

Zheng 2003

Zheng Jin 郑瑾. “Ming-Qing shiqi de haidao yu difang jiceng shehui” 明清时期的海盗与地方基层社会 (Pirates and the Local Society during the Ming and Qing Eras). In Di jiujie Mingshi guoji xueshu taolunhui ji Fu Yiling 
jiaoshou danchen jiushi zhounian jinian lunwen ji 第九届明史国际学术讨论会暨傅衣凌教授诞辰九十周年纪念 论文集 (The Ninth International Symposium on the History of the Ming: In Memory of Prof. Fu Yiling's 9oth Anniversary), ed. Chen Zhiping 陈支平, pp. I50-52. Xiamen: Xiamen University Press, 2003.

Zurndorfer 2016

Zurndorfer, Harriet. "Oceans of History, Seas of Change: Recent Revisionist Writing in Western Languages about China and East Asian Maritime History during the Period I500-1630." International Journal of Asian Studies I3:I (20I6), pp. 6I-94. 